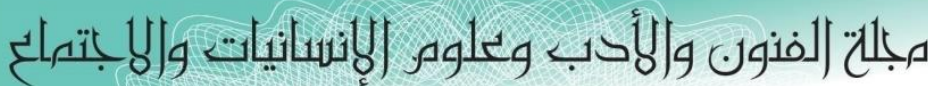

Journal of Arts, Literature, Humanities and Social Sciences

ISSN online: 2414 - 3383

ISSN print: 2616 - 3810

العدد (42) أيلول - لسبتمبر 2019

\title{
فاعلية توظيف استراتيجية التعلم المقلوب في تنمية معارف ومهارات التشكيل على الماتيكان
}

\author{
د. ـ نجلاء جابر ضيف الله الثبيتي \\ أستاذ مساعد بقسم تصميم الأزياء

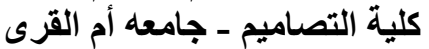 \\ المملكة العربية السعودية المئم
}

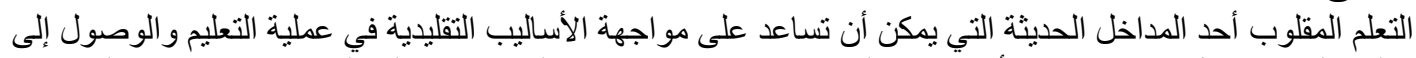

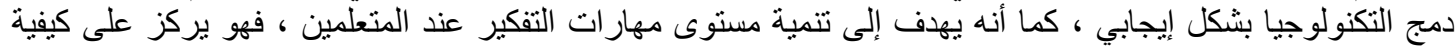

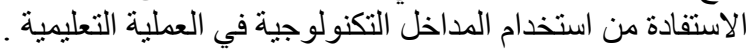

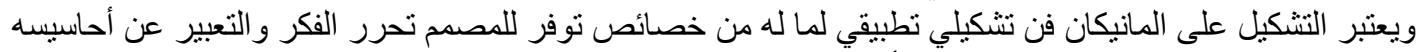

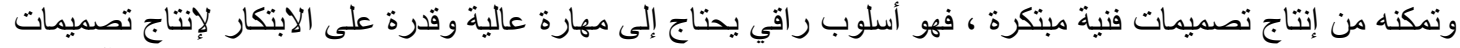

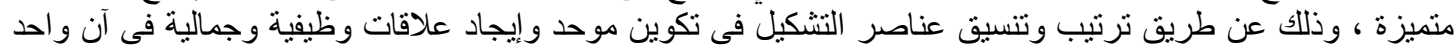

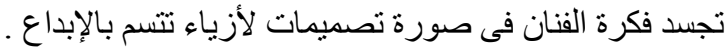

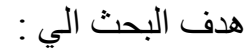

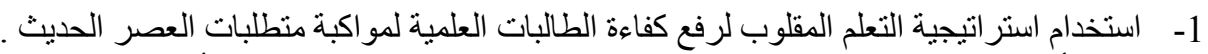

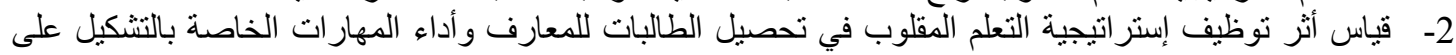
المانيكان.

3- ملاحقة التطور ات التكنولوجية السريعة في العصر الحديث وما يتطلبه ذلك من تتمية قدرات ومهارات.

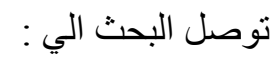
1- توجد فروق دالة إحصائياً بين متوسطي درجات الطالبات في التطبيق القبلي والبعدي للاختبار التحصبلي والاختبار المهاري

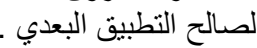
2- توجد فروق دالة إحصائياً بين متوسطي درجات الطالبات في التطبيق القبلي و البعدي للاختبار التحصيلي لصالح التطبيق البعدى 3- توجد فروق دالة إحصائياً بين متوسطي درجات الطالبات في التطبيق القبلي والبعدي للاختبار المهاري لصالح التطبيق البعدى

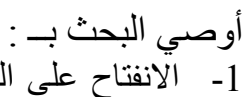

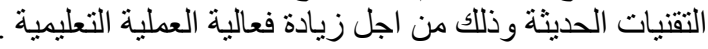

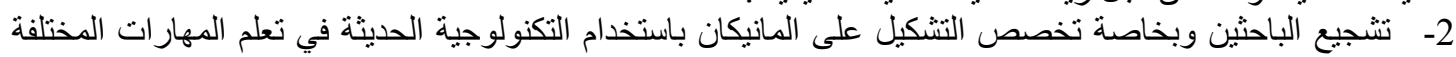

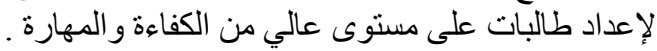

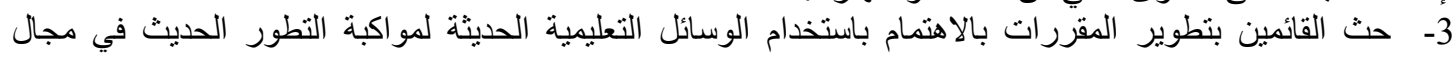

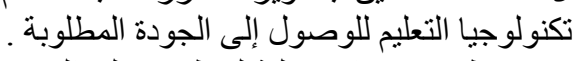

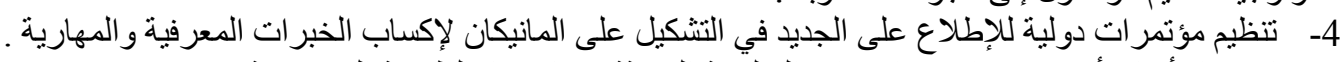
5- استخدام أنو اع أخري من الاستر اتيجيات التعليمية الحديثة ومقارنتها بالطريقة المستخدمة . 


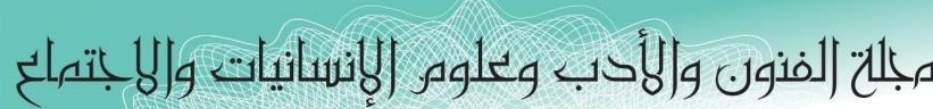 \\ Journal of Arts, Literature, Humanities and Social Sciences \\ ISSN online: 2414 - 3383 \\ ISSN print: 2616 - 3810 \\ أيلول - سبتمبر 2019 \\ العدد (42) \\ The Effectiveness of Employing the Inverted Learning Strategy in Developing Knowledge and Skills of Formation on the Mechanic
}

\begin{abstract}
Inverted learning is a modern approach that can help to counter traditional methods in the learning process and reach a positive integration of technology.It also aims to develop the level of thinking skills of learners.It focuses on how to benefit from the use of technological approaches in the educational process.

Formation on the manikin is applied art because of its characteristics to provide the designer free thought and expression of his feelings and enable him to produce innovative art designs, it is a sophisticated style requires high skill and innovation ability to produce distinct designs, by arranging and coordinating elements of formation in a unified composition and find Functional and aesthetic relationships simultaneously embody the artist's idea in the form of creative fashion designs.
\end{abstract}

The research aims to:

1 - Use the inverted learning strategy to raise the efficiency of scientific students to cope with the requirements of modern times.

2 - Measure the impact of using the inverted learning strategy in the achievement of students' knowledge and performance of skills on the formation of the formation.

3 - Following up the rapid technological developments in the modern era and the required development of abilities and skills.

The research reached:

1- There are statistically significant differences between the average scores of students in the pre- and post-application of achievement test and skill test in favor of post-application.

2 - There are statistically significant differences between the average scores of students in the pre- and post-application of achievement test in favor of post-application.

3 - There are statistically significant differences between the average scores of students in the pre - and post - application of the skill test in favor of the post - application.

I recommend Search by:

1 - Openness to the world and access to modern methods of education through the integration of modern educational strategies with modern technologies in order to increase the effectiveness of the educational process.

2 - Encouraging researchers, especially the formation on the mechanics using modern technology in learning different skills to prepare students at a high level of competence and skill.

3 - Urging those who develop courses to pay attention to the use of modern educational means to keep pace with the recent development in the field of educational technology to reach the required quality.

4 - Organize international conferences to see the new formation on the Manikin to acquire knowledge and skills.

5. Use other types of modern educational strategies and compare them with the method used. 


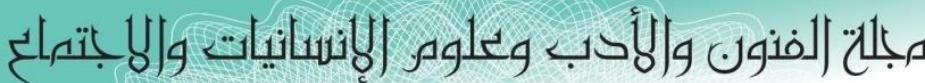

Journal of Arts, Literature, Humanities and Social Sciences

ISSN online: 2414 - 3383

ISSN print: 2616 - 3810

\section{العدد (42) أيلول - سبتمبر 2019}

التعلم المقلوب أحد المداخل الحديثة التي يمكن أن تساعد على مواجهة الأساليب التقليدية في عملية التعليم

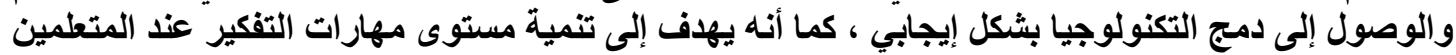
، فهو يركز على كيفية الاستفادة من استخدام المداخل التكنولوجية في العملية التعليمية (حنان الزين :

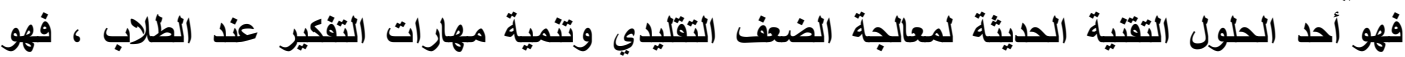

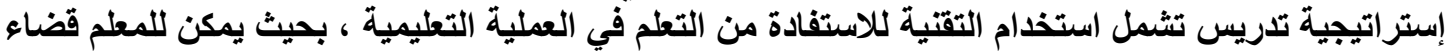

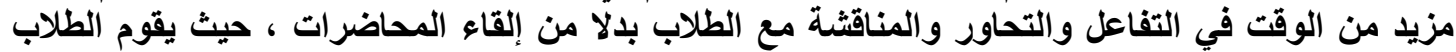
بمشاهدة فيديو قصير للمحاضرات في المنزل ، ليتم استغلال الوقت الأكبر لمناب لمناقثة المحتوى في الفصل تحت

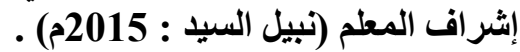

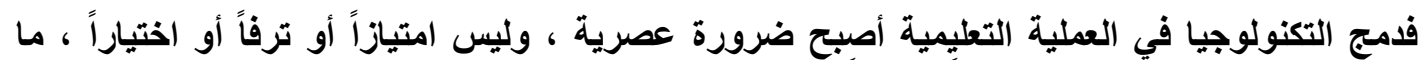

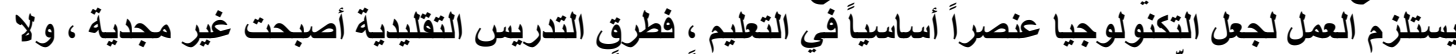

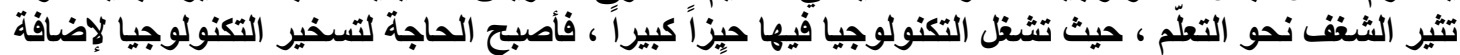
الإثارة والتشويق لعناصر البيئة التعليمية المتعددة لتلبية الاحتياجات الفرديّة والخاصّة لكل طالب (عبد اللطيف الليف

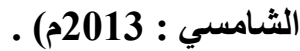

ويعد أحد أنواع التعلم المدمج الذي يستخدم التقتية لنقل المحاضرات خارج الفصل الداراسي ، وبذلكت يعتبر

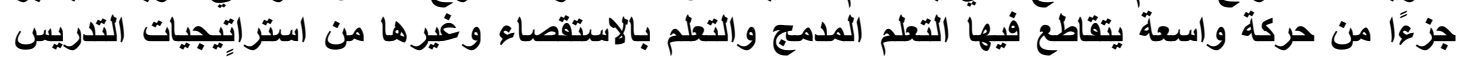
وأساليبه المختلفة التي تسعى إلى المرونة وتفعيل دور الطالب وجعل التعلم ممتعًا ومشوقًا (حنان اسعد :

فالتعلم المقلوب هو تغيير لواقع غرفة الصف بحيث تصبح المبح المحاضرات واجبًا منزليًا ، مما يتيح وقتنًا لمزيد

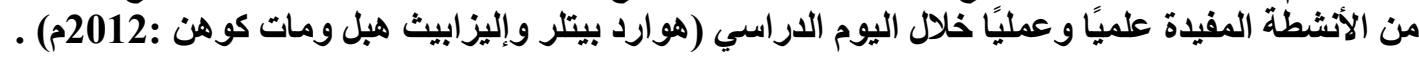

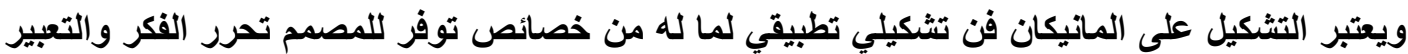

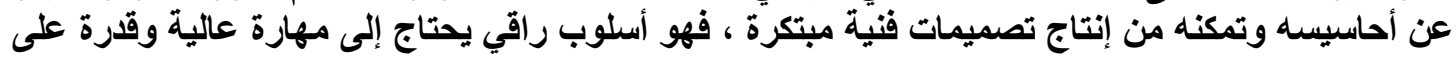

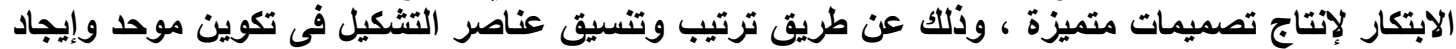

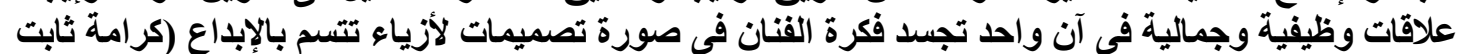

. (2016 :

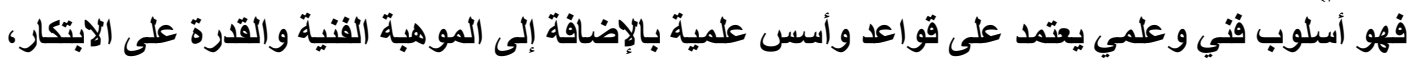

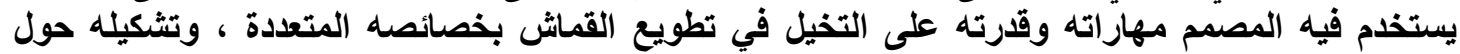
الجسم أو المانيكان لإبداع تكوين فني في انسجام تام بين جميع عناصر وأسس التشكيل (نجوى شكري :

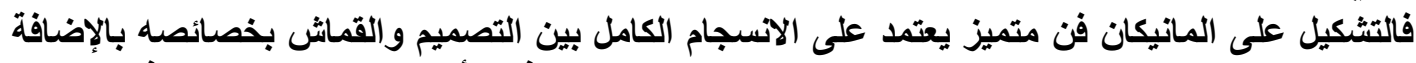

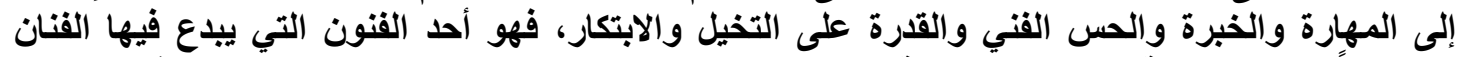

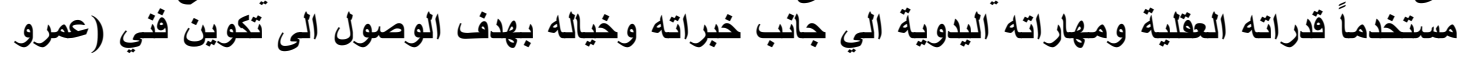

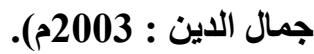

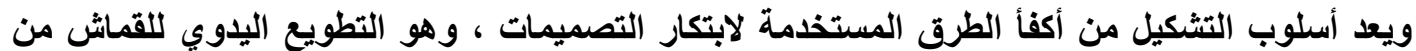

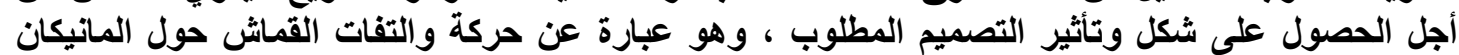

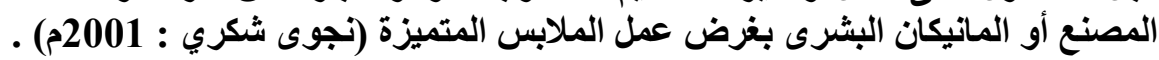

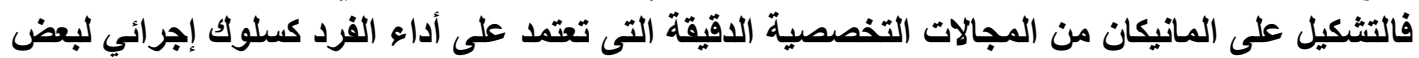

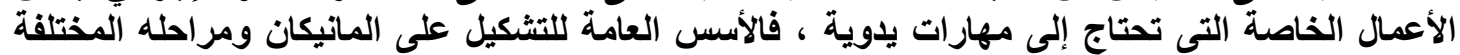

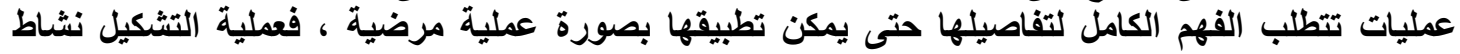




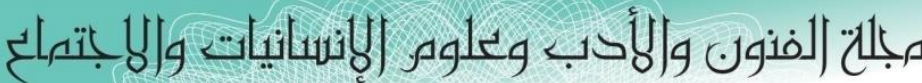

Journal of Arts, Literature, Humanities and Social Sciences

ISSN online: 2414 - 3383

ISSN print: 2616 - 3810

\section{أيلول -سبتمبر 2019}

العدد (42)

ابتكاري يجمع بين العقل والأداء الحركي ، أي بين القدرة العقلية والأداء الحركي ، فهي عملية تنطلب الجمع

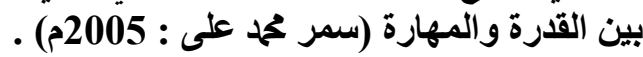

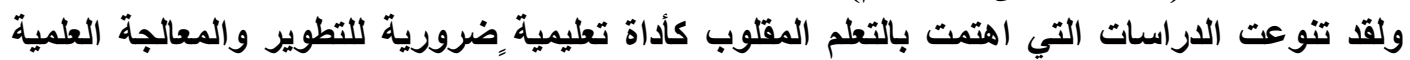

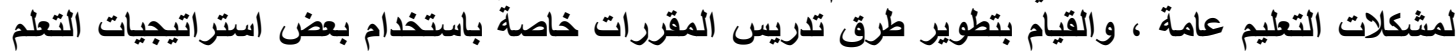

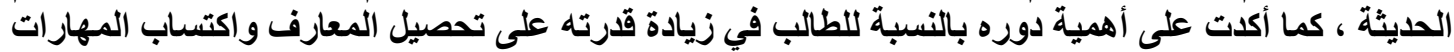

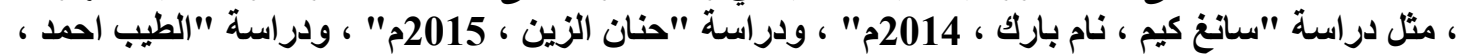

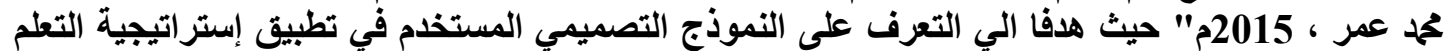

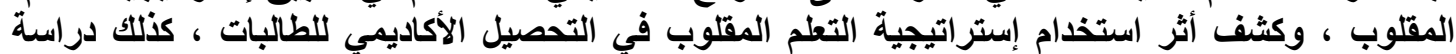

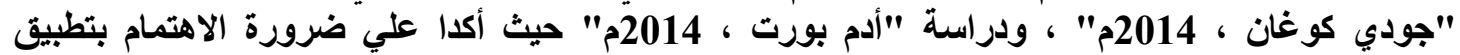

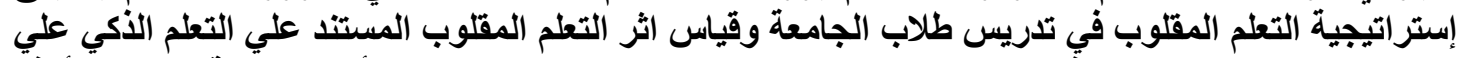

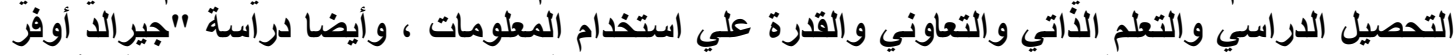

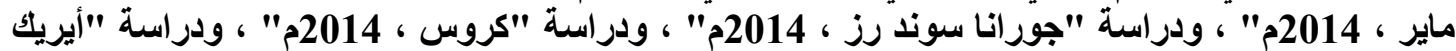
شوانكي ، 2013م" حيث هدفا الي استطلاع رأي الطلاب حول تجريتهم واتجاهاتهم نحو التعلم المقلوب في ودري

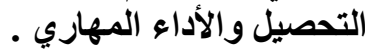

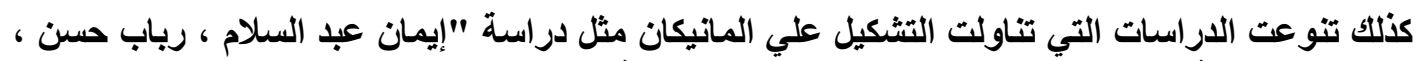

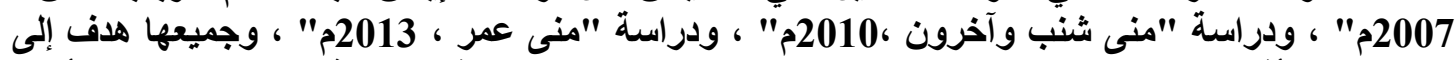

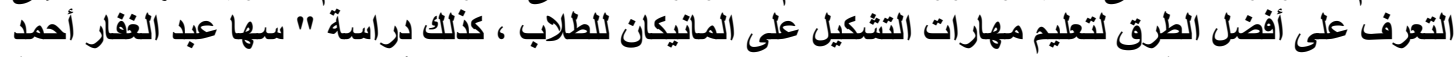

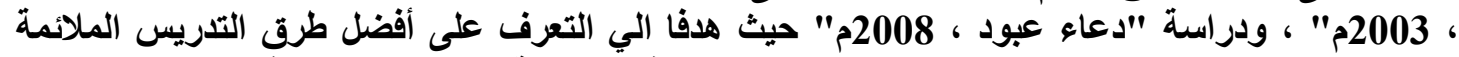

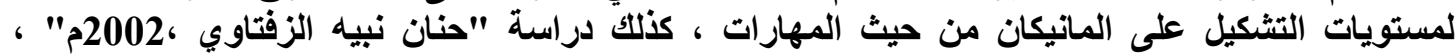

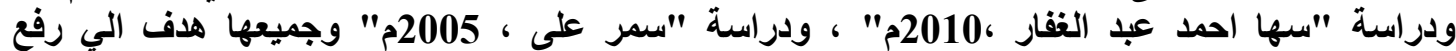

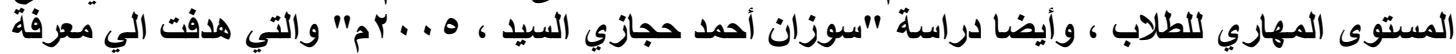

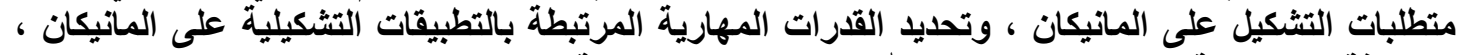

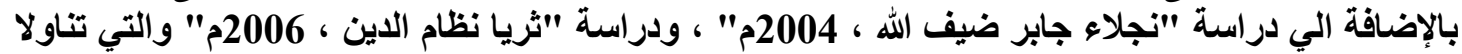

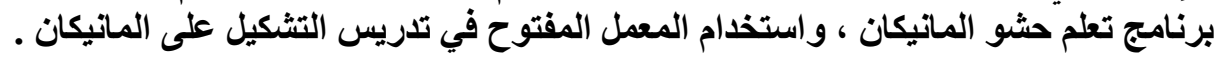

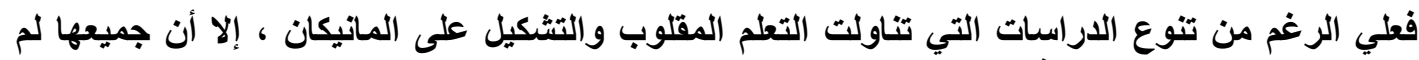

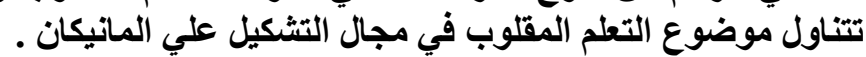

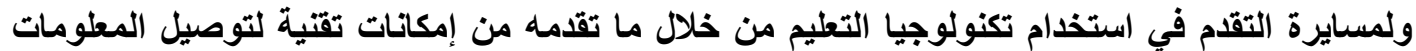

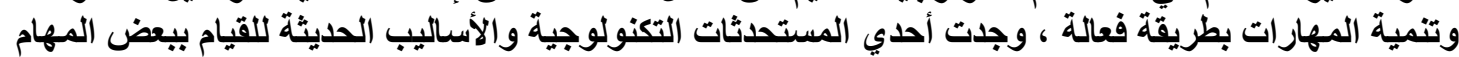

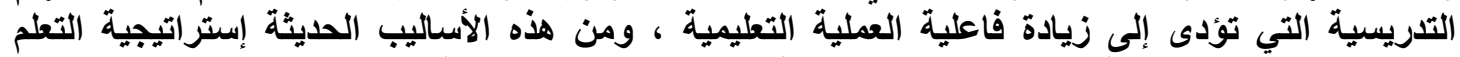

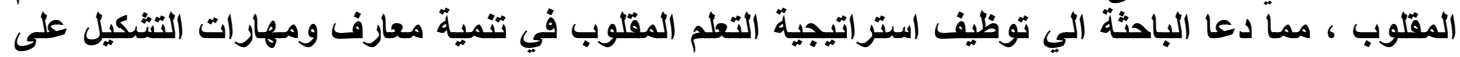

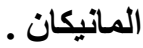

مشكلة البحثة:

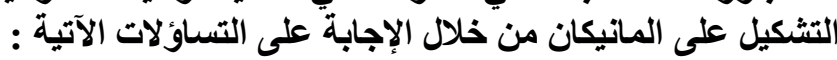

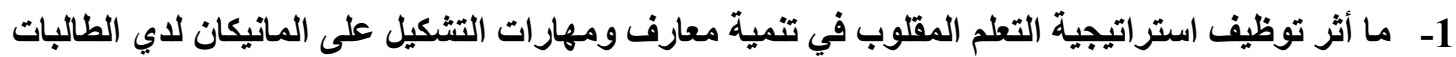
2- ما مدي فاعلية إستراتيجية التعلم المقلوب على تحصيل الطالبات للمعارف الخاصة بالتثكيل على المانيكان ؟ مل 3- ما مدي فاعلية إستراتيجية التعلم المقلوب في إكساب الطالبات للمهارات الخاصة بالتشكيل على المانيكان؟ 
مبلحة لفنون والأدب وعلوه الإنسانيات و|لابتهماع

Journal of Arts, Literature, Humanities and Social Sciences

ISSN online: 2414 - 3383

ISSN print: 2616 - 3810

\section{العدد (42) أيلول -سبتمبر 2019}

LALLHSS

www.jalhss.com

أهداف البحث :

اليهاف البحث الحالي إلى التعرف على فاعلية توظيف استراتيجية التعلم المقلوب في تنمية معارف ومهارات

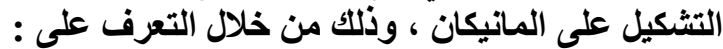

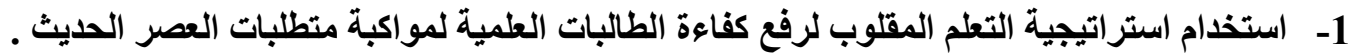

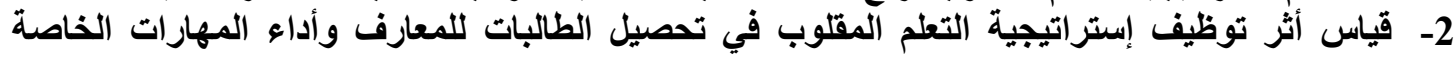
بالتشكيل على المانيكان . 3- ملاحقة التطورات التكنولوجية السريعة في العصر الحديث وما يتطلبه ذلك من تنمية قدرات ومهارات. 1 أهمية البحث :

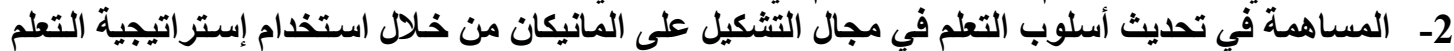
المقلوب بما يتماشى مع الاتجاهات الحديثة في التدريس. 3- إعداد خريجات تتوافر فيها القدرات المعرفية والمهارية التي تؤهلهم لمواكبة التطور التكنولوجي في مجال

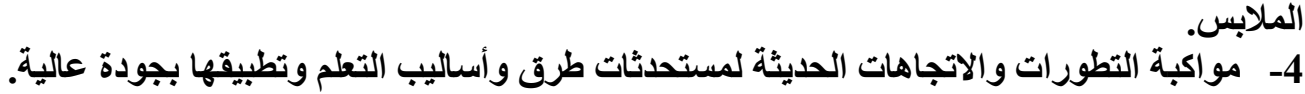

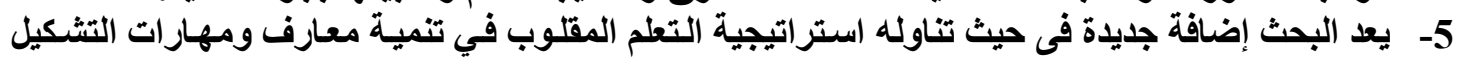
على المانيكان . الأسلوب البحثي : البحث :

1- توجد فروق دالة إحصائياً بين متوسطي درجات الطالبات في التطبيق القبلي والبعدي للاختبار التحصيلي والاختبار المهاري لصالح التطبيق البعدي . 2- توجد فروق دالة إحصائياً بين متوسطي درجات الطالبات في التطبيق القبلي والبدي للاختبار التحصيلي لصالح

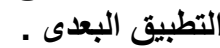
3- توجد فروق دالة إحصائياً بين متوسطي درجات الطالبات في التطبيق القبلي والبعدي للاختبار المهاري لصالح

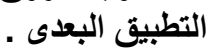

$$
\text { ـ مصطلحات البحث : الفاعلية : }
$$

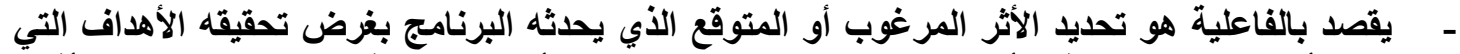

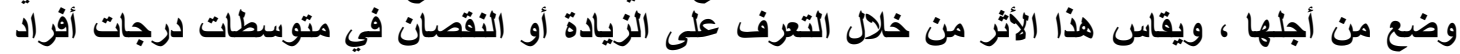

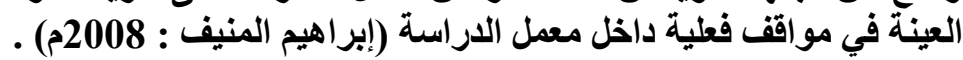

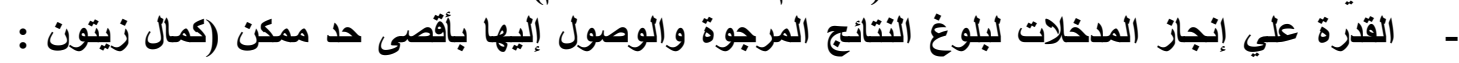

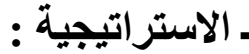
- الاستراتيجية هي خطة محكمة البناء ومرنة التطبيق يتم من خلالها استخدام كافة الامكانيات والوسائل

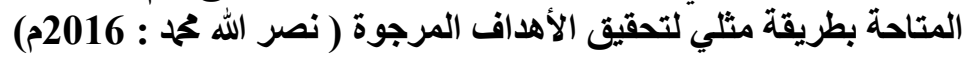

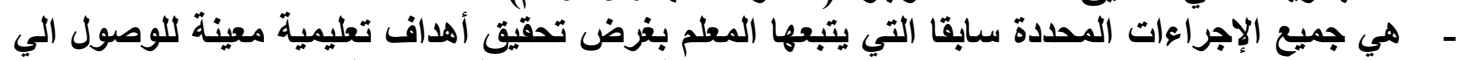
مخرجات تعليم محددة ، وهذا يعني التخطيط الثامل لكيفية تنفيذ العملية التعليمية وتقويمها (بهيرة شفيق لتهية

. (2015:

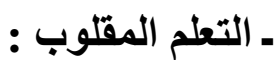

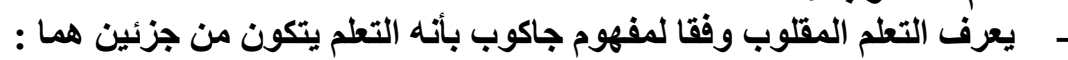
أنشطة تعلم تفاعلية لمجموعات صغيرة داخل المحاضرة . 


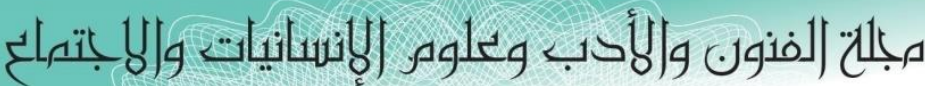

Journal of Arts, Literature, Humanities and Social Sciences

ISSN online: 2414 - 3383

ISSN print: 2616 - 3810

\section{العدد (42) أيلول - سبتمبر 2019}

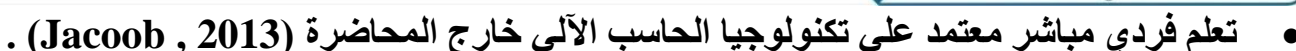

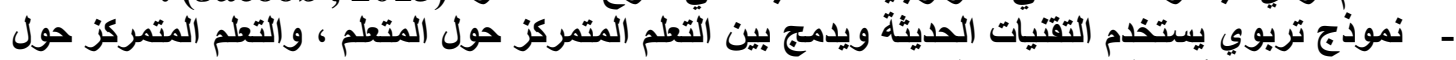

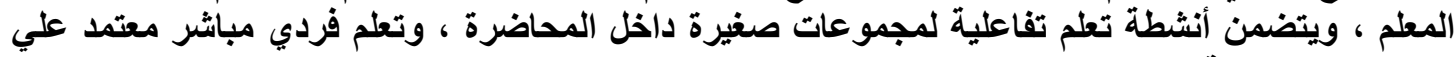
التكنولوجيا الحديثة (الطيب احمد ، محم عمر : 2015م) .

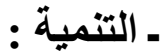

ـ الجها المنظم لاستغلال الإمكانيات المادية والطاقات البشرية المتوفرة في المجتمع لتحقيق حاجاته الحقيقية المختلفة تحقيقًا متوازناً (تحما منير حجاب : 2013 م) .

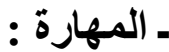
ـ ـ القدرة على إحاثث أثر مقصود على نحو منسق وبدقة مع السرعة والاقتصاد في العمل (إبراهيم حسن: (2008) - مجموعة استجابات الفرد الأدائية المتناسقة التي تنمو بالتعلم والممارسة حتى تصل إلى درجة عالية من

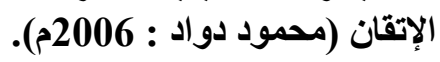

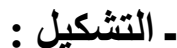
ـ ـ تطويع القماش وفقا لعناصر وأسس معينة بواسطة مهارات خاصة للوصول إلى منتج أو تصميم مبتكر له

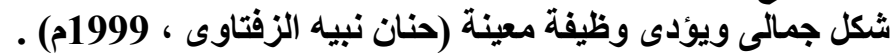

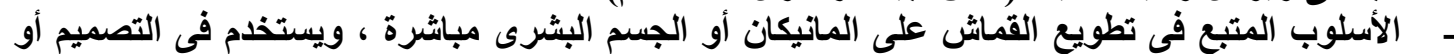
الحصول على النماذج أو فى تعديل ومطابقة النماذج النى صنعت بالطرق المسطحة (سها الحمد ، 2010م) .

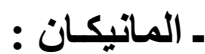
- ألداة من الأدوات الرئيسية المستخدمة في التثكيل والتي تمثل شكل الجسم البشري في صورة قالب ثلاثي

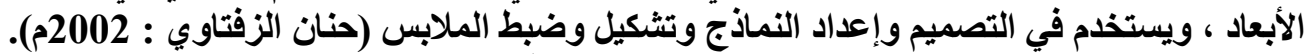

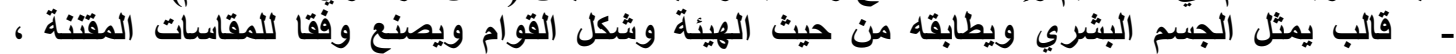

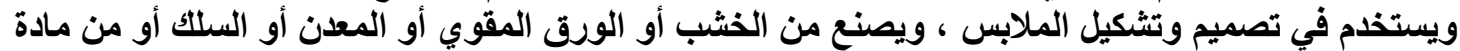

مطاطة (نجوى شكري : 2001م).

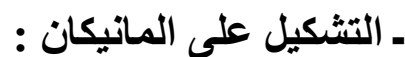

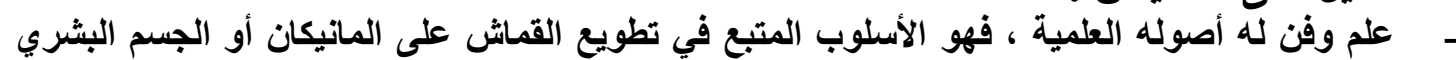

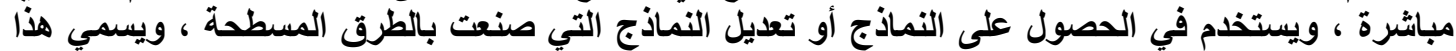

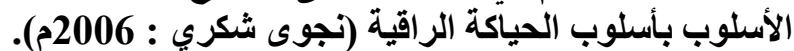

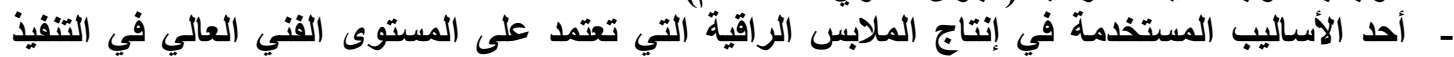
و الخامات الممتازة من الأقشّة والكلف والإكسسوارات ذات القيمة المرتفعة (عبد القادر وآخرون ، 2003م). يتحدد منهج البحث عادة في إطار فكرته وأهدافه وفعاليته وإجراءاته ، ويناءاً على ذلك فأن البحث الحالي

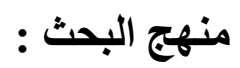
يتبع منهجين هما : البحث

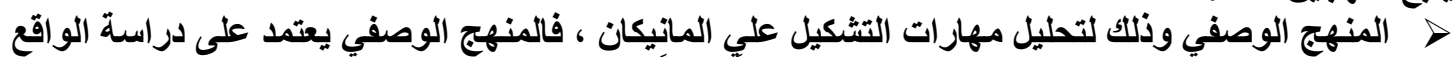

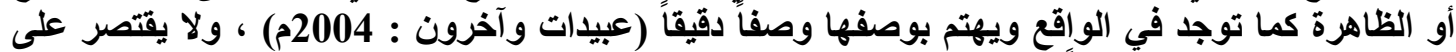

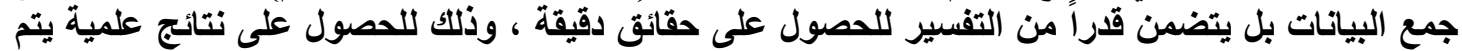

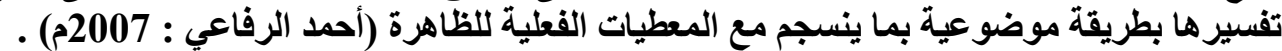

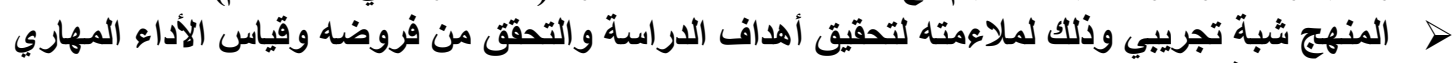
و التحصيل المعرفي المرتبط بمهارات التثكيل علي المانيكان .

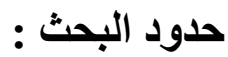

تعلم معارف ومهارات التثكيل على المانيكان من خلال توظيف استراتيجية التطم المقلوب . 


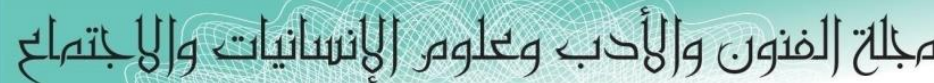

Journal of Arts, Literature, Humanities and Social Sciences

ISSN online: 2414 - 3383

ISSN print: 2616 - 3810

العدد (42) ايلول -سبتمبر 2019

LALHSS

www.jalhss.com

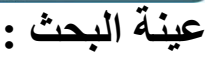

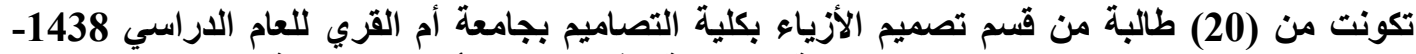
1439هـ / 1440-1439هـ ، تم اختيارهم بطريقة عشوائية وذلك لتطبيق أدوات الاراسة عليهم واستخلاص

النتائج ومناقشتُها.

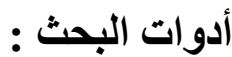

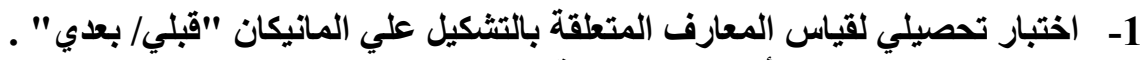

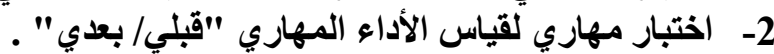

3- مقياس تقدير لقياس مهارات التشكيل علي المانيكان .

التعلم المقلوب النظري:

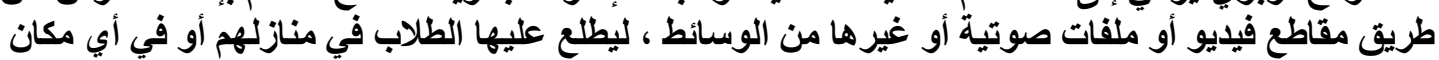

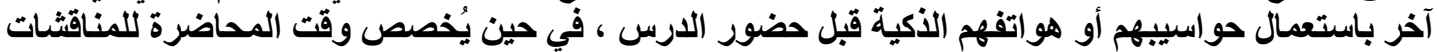

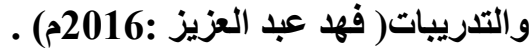

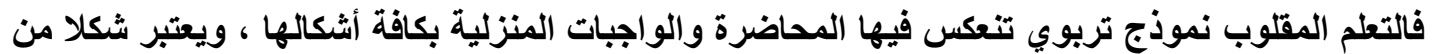

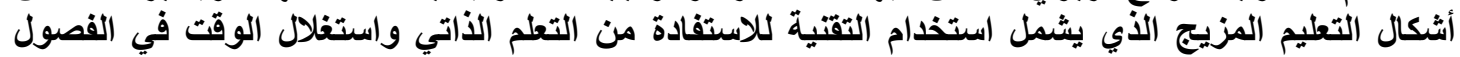

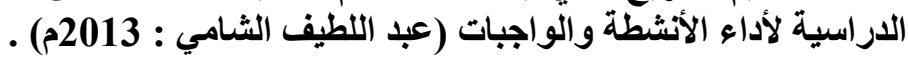

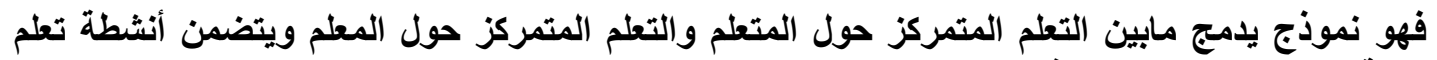

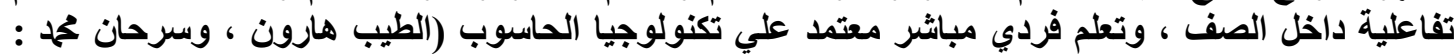

(2015

ميزات إستر اتيجية التعلم المقلوب : مئيز

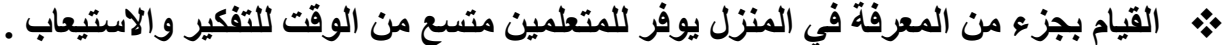

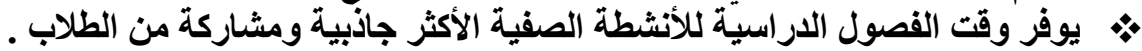

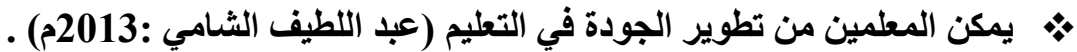

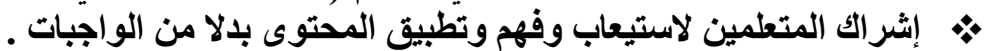

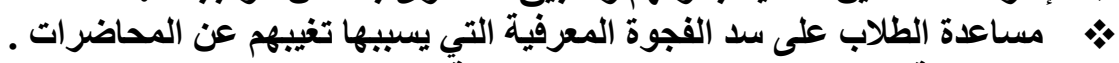

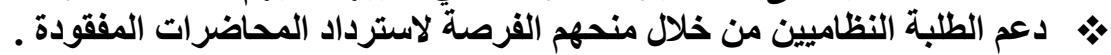

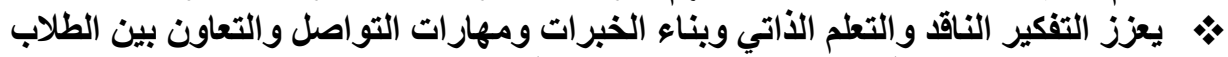

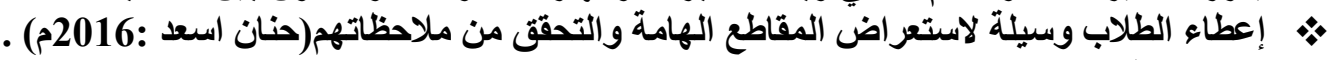
• المحتوى قصير وممتع ويسهل استيعابه (marlowek,c:2012).

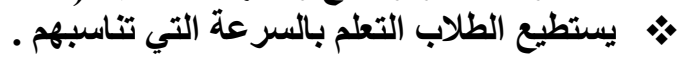

(http://eduongo.net/2013/10/29/bill-gates-talks about-flipped-learning)

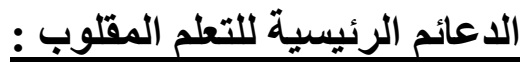

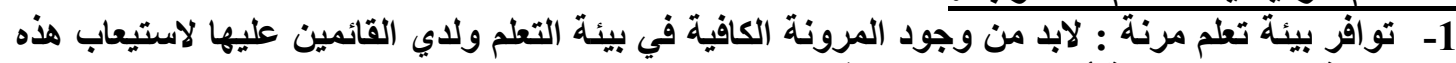

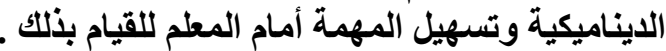

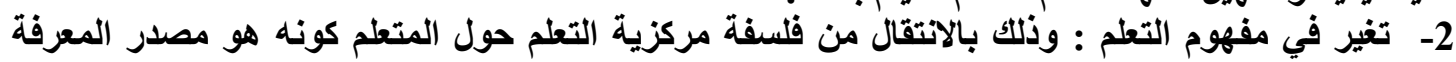

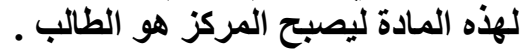

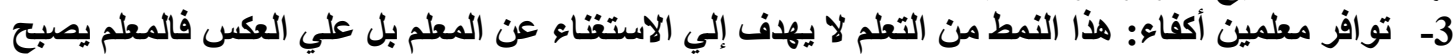

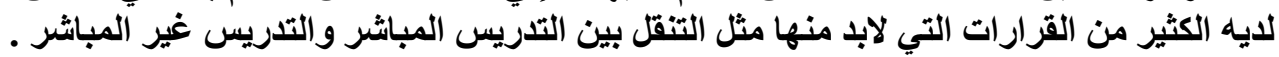




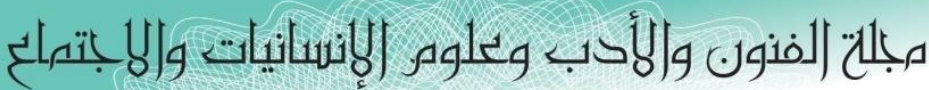

Journal of Arts, Literature, Humanities and Social Sciences

ISSN online: 2414 - 3383

ISSN print: 2616 - 3810

\section{العدد (42) ايلول - سبتهبر 2019}

4- التفكير الدقيق في تقسيم المحتوي وتحليله : وذلك لتحديد ما سيتم تقسيمه من المحتوي عن طريق

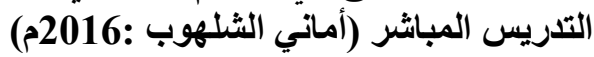

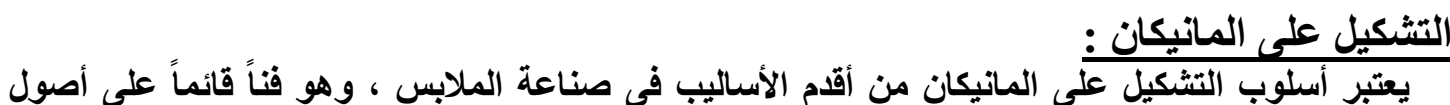

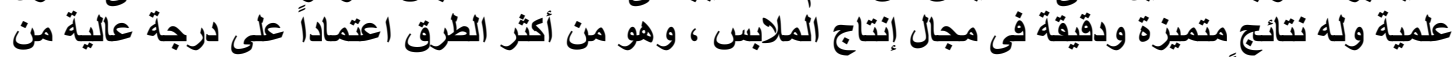

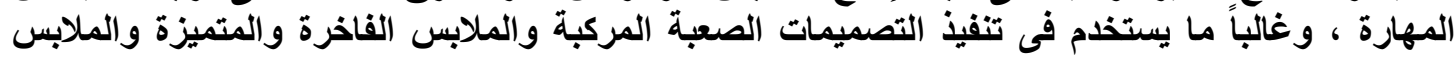

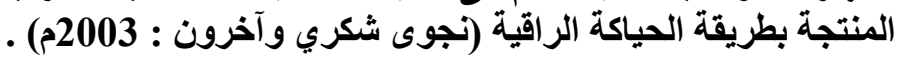

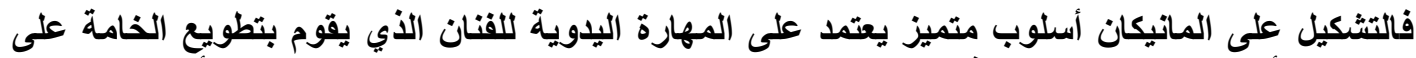

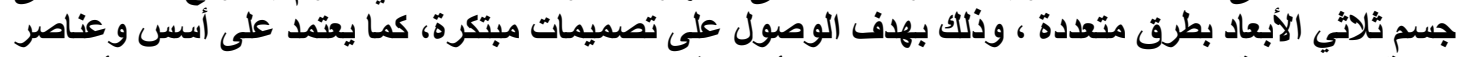

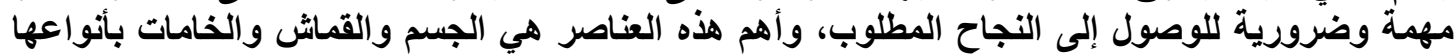

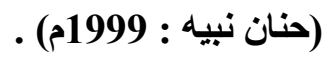

فهو أحد أساليب إعداد وتصميم النماذج المجسمة للملابس ، ويستخدم في عملية تنفيذ الملابس ، وهئ وهذا الأسلوب يعتبر أسلوباً خاصاً بالتصميمات المتميزة ، والتي يصعب تنفيذها عن طريق التهابئ النماذج الورقية ،

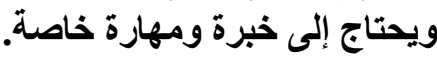

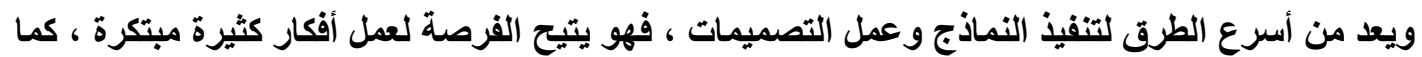

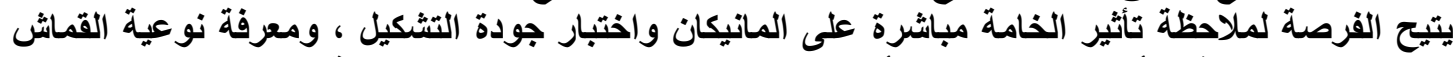

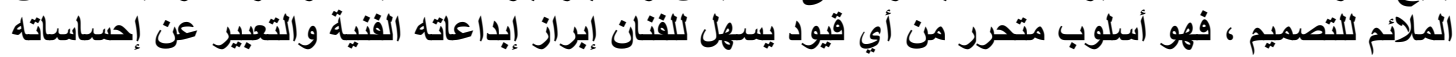

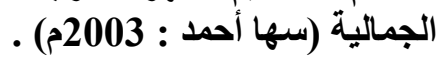

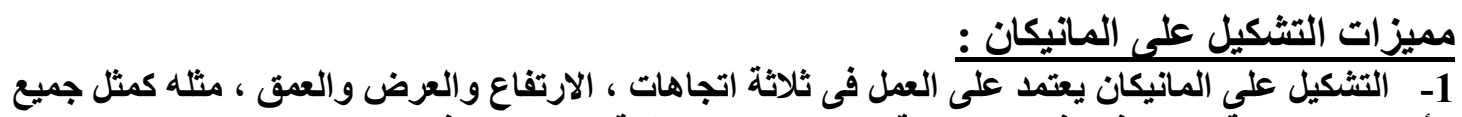

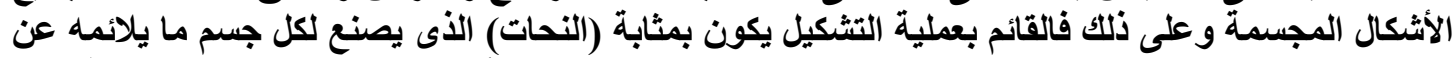
طريق إحساسه بالحجم وشكله ، حيث يتم التشكيل على المانيكان مباشرة أو الجسم البشرى نفية نفسه (كرامة ثابت . (2016 : 2- طريقة سهلة وسريعة للحصول على النماذج لمن تتوافر لايهم الاراسة والخبرة .

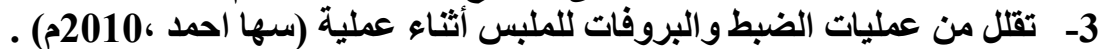

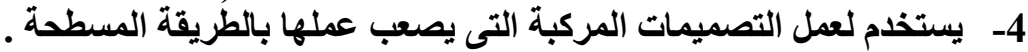

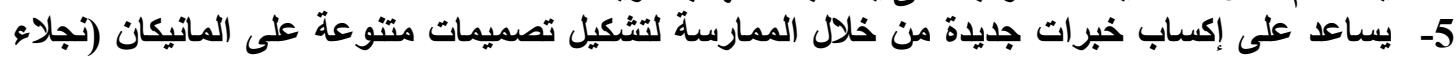

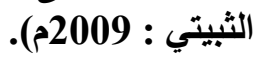

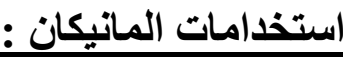

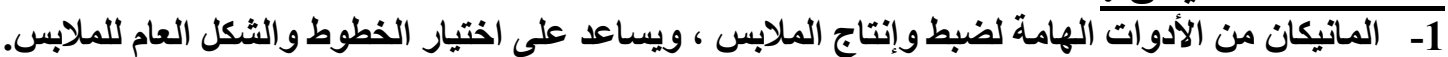

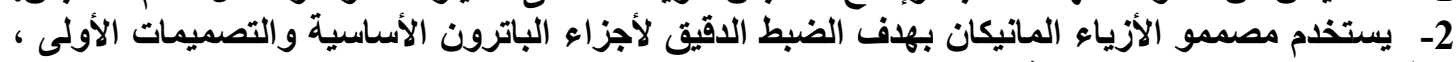

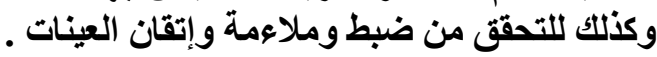

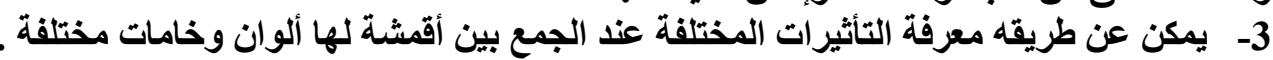

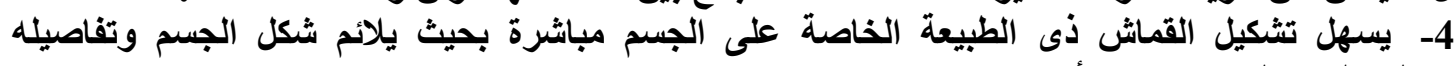

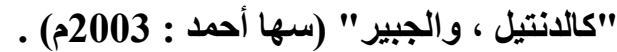

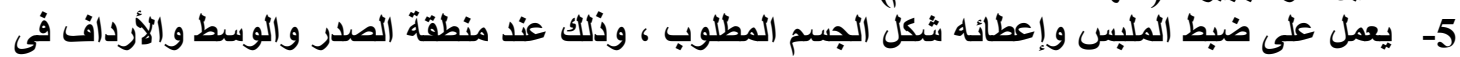

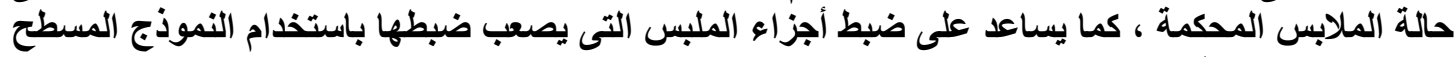
، ويساعد على إعطاء تفاصيل الجسم بشكلة الصيلة الصحيح .

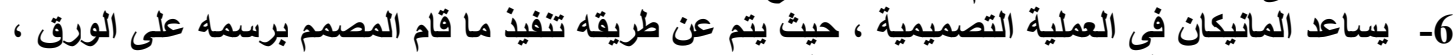

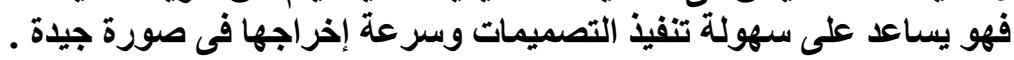




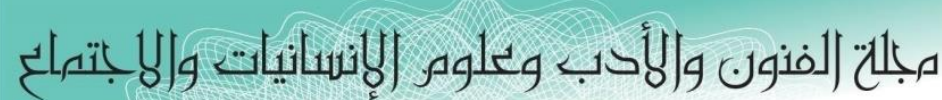
Journal of Arts, Literature, Humanities and Social Sciences

ISSN online: 2414 - 3383

ISSN print: 2616 - 3810

أيلول - سبتمبر 2019

العدد (42)

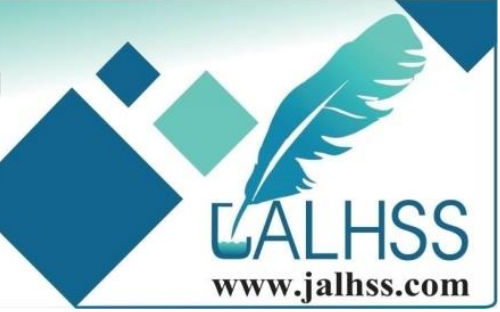

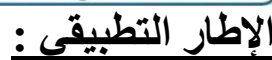

تم تنفيذ مجموعة من التصميمات من قبل الطالبات بتوظيف استراتيجية التعلم المقلوب لتنمية مهارات التشكيل على المانيكان ، وفيما يلي عرض لمجموعة التصميمات المنفةة :

شكل (1) نماذج من التصميمات المنفذة

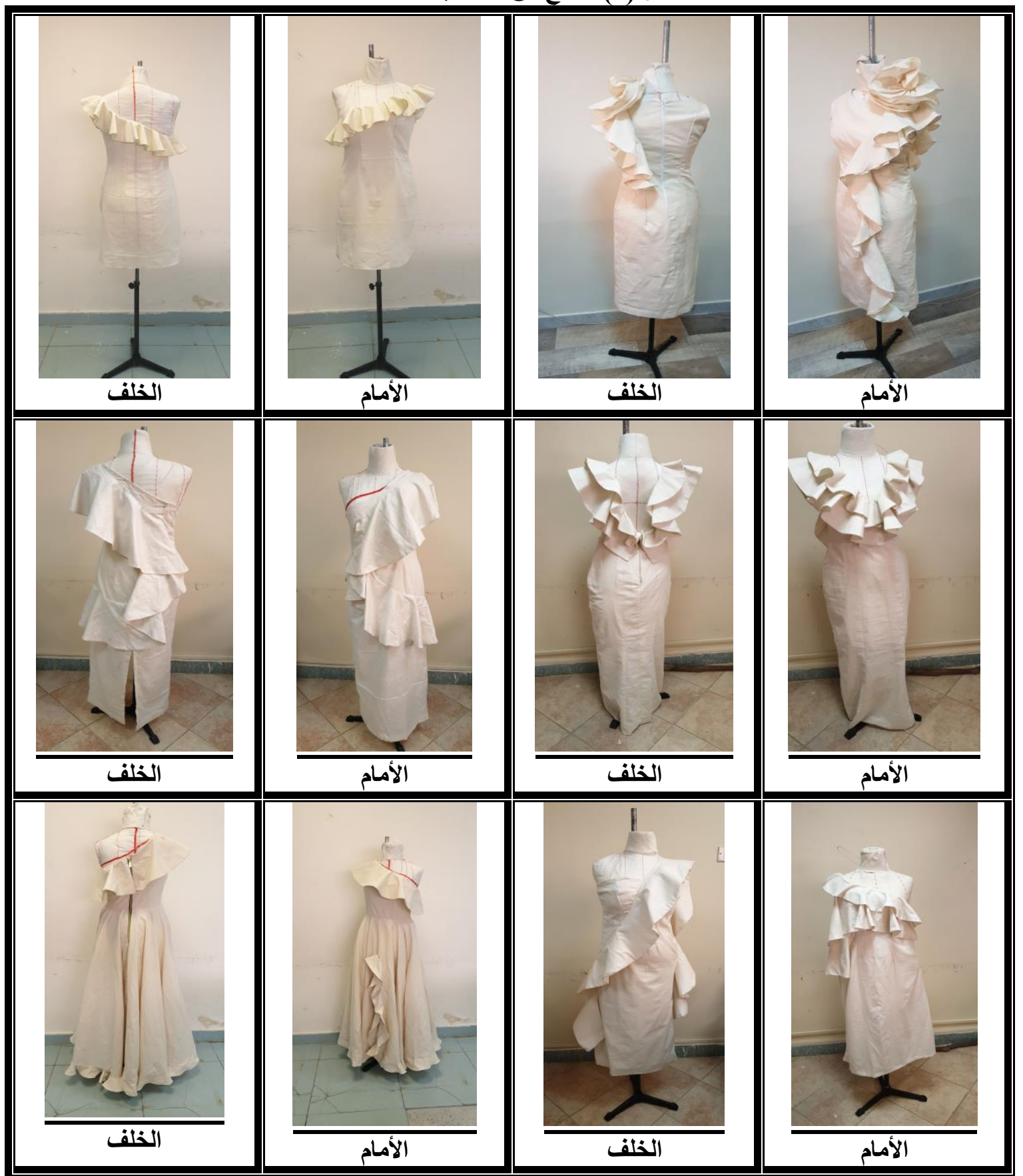




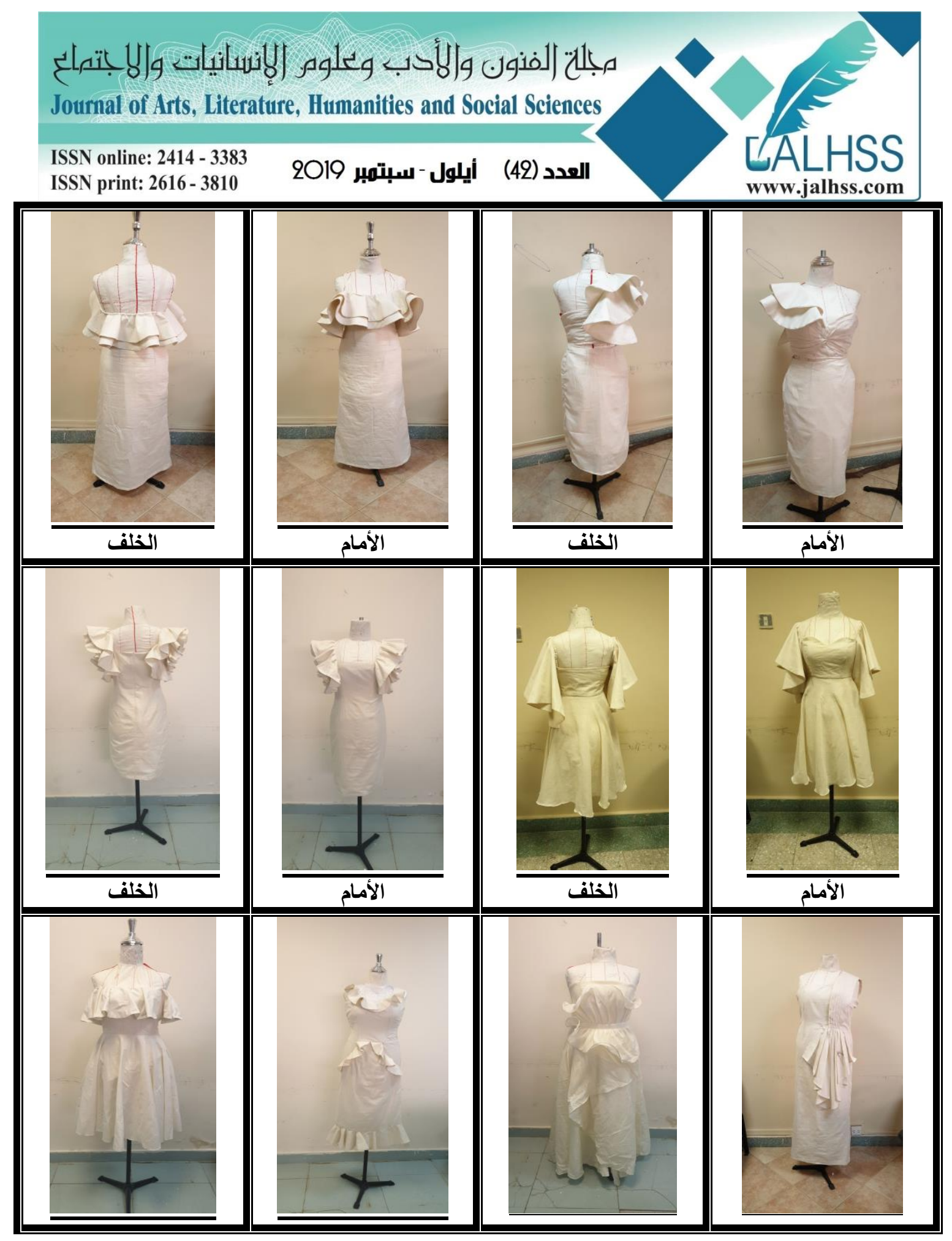




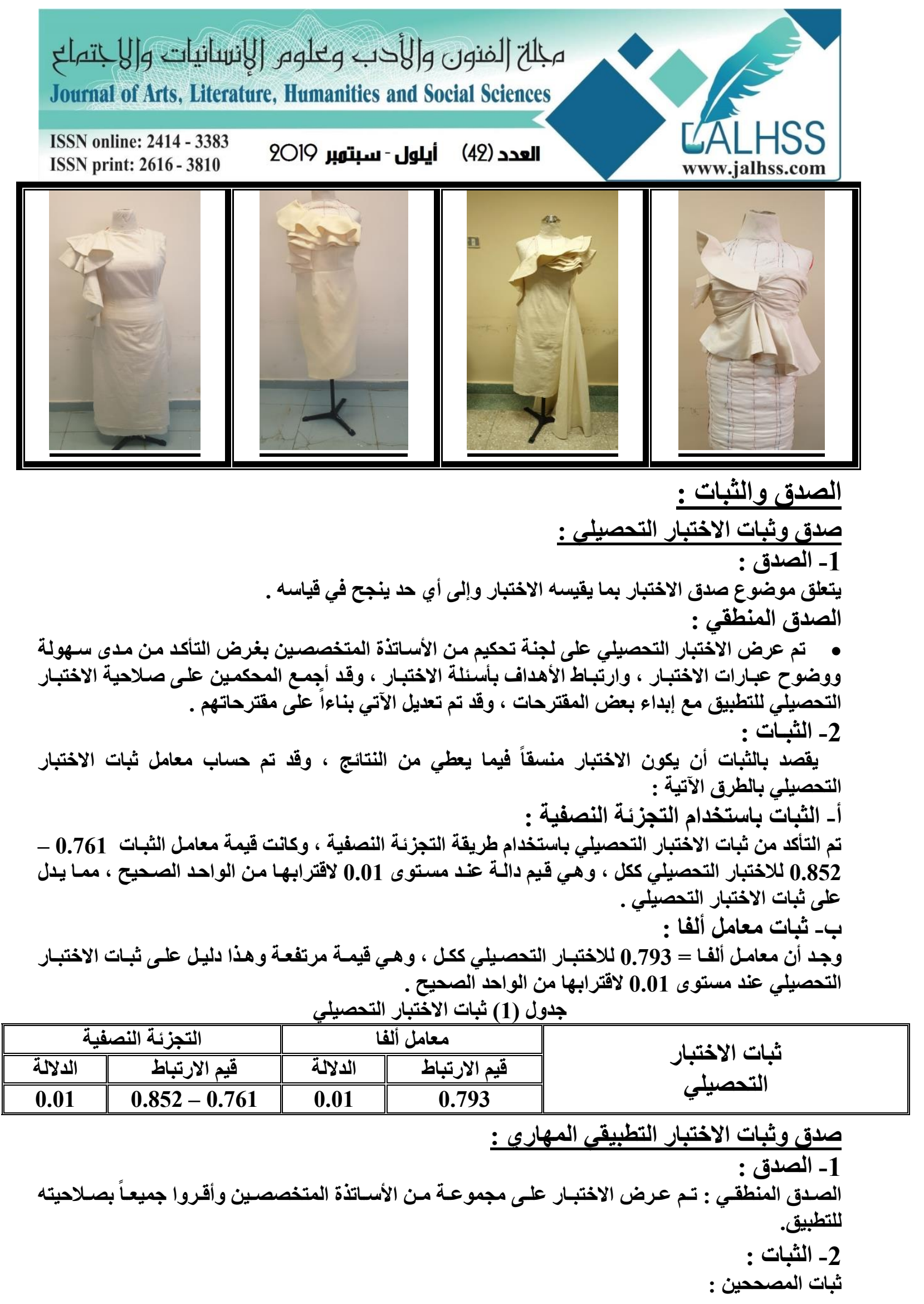




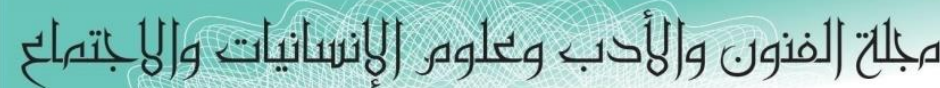

Journal of Arts, Literature, Humanities and Social Sciences

ISSN online: 2414 - 3383

ISSN print: 2616 - 3810

\section{العدد (42) أيلول - سبتهبر 2019}

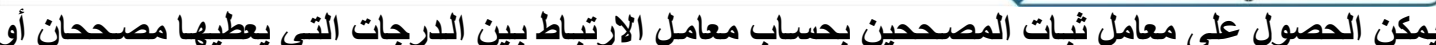

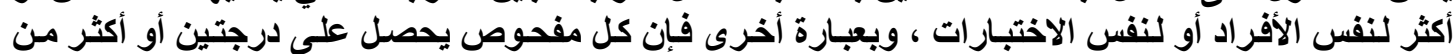

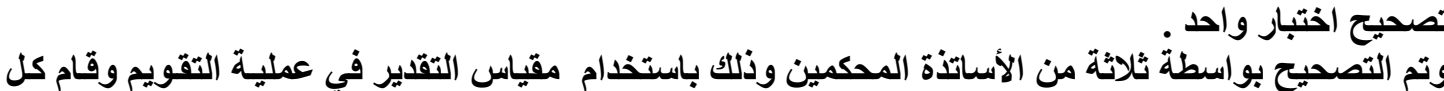
مصحح بعملية التقويم بمفرده .

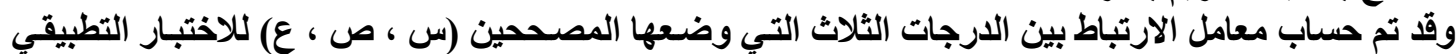

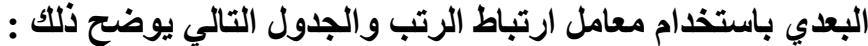

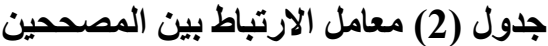

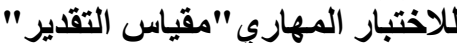

\begin{tabular}{|c|c|}
\hline مقياس التقدير ككل & المصححين \\
\hline 0.732 & س ، ص \\
\hline 0.915 & س ، ع \\
\hline 0.888 & ص، ع \\
\hline
\end{tabular}

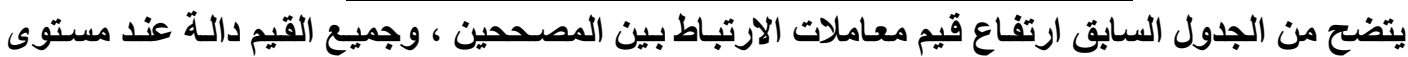

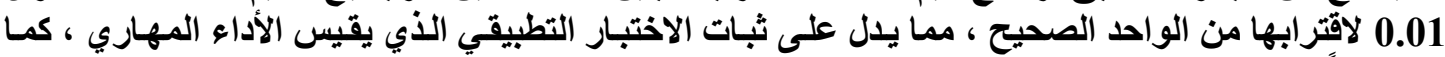

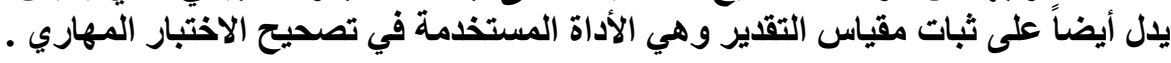
تالفـرضج البحث : الأول:

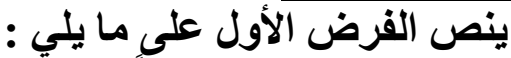

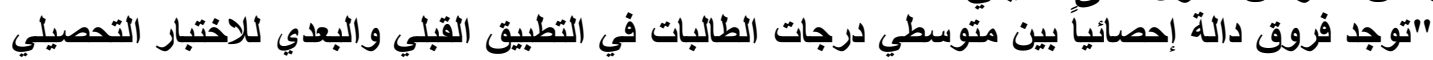

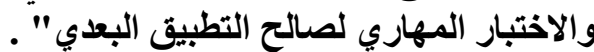

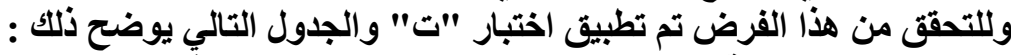

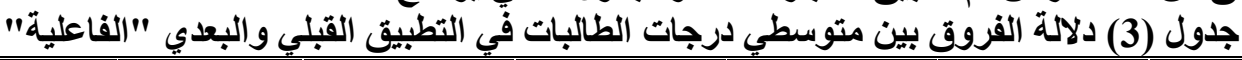

\begin{tabular}{|c|c|c|c|c|c|c|}
\hline مستوى الدلالة & قيمـة ت & "الدرجــة & عدد ألفزينة & 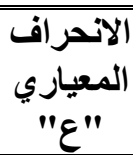 & "الحستوسطي & الفاعلية \\
\hline \multirow{2}{*}{ لصالح البعدي } & \multirow{2}{*}{49.112} & \multirow{2}{*}{19} & \multirow{2}{*}{20} & 6.120 & 66.744 & القبلـي \\
\hline & & & & 12.028 & 473.682 & البعـدي \\
\hline
\end{tabular}

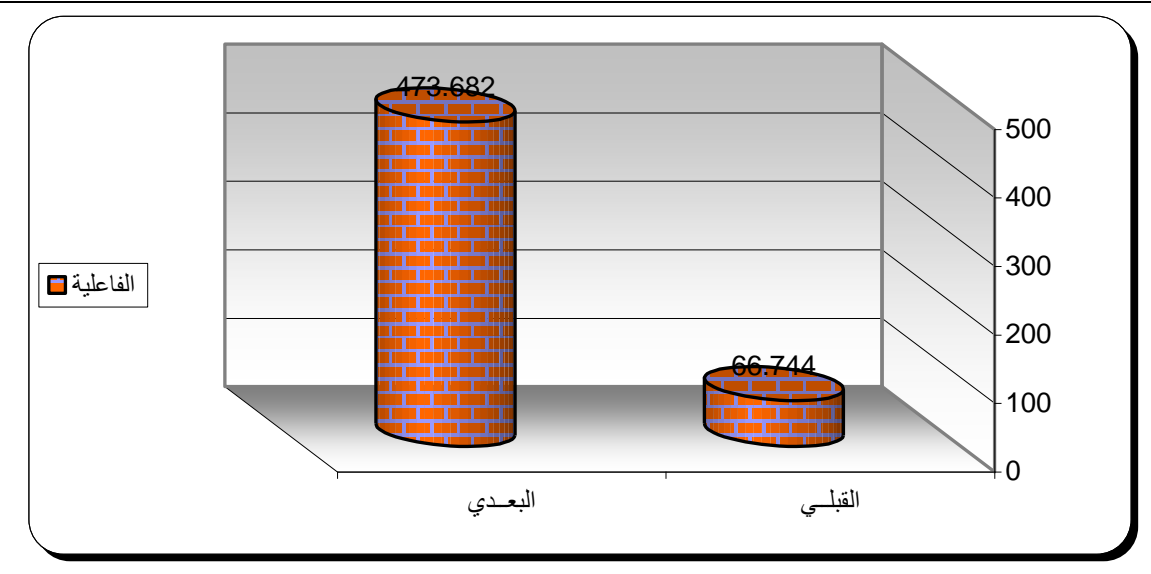

شكل (2) دلالة الفروق بين متوسطي درجات الطالبات في التطبيق القبلي والبعدي "(لفاعلية" 


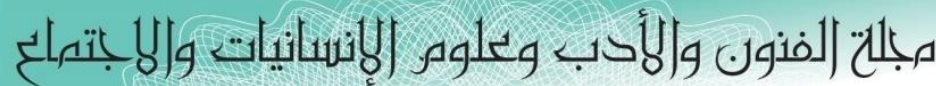

Journal of Arts, Literature, Humanities and Social Sciences

ISSN online: 2414 - 3383

ISSN print: $\mathbf{2 6 1 6}$ - $\mathbf{3 8 1 0}$

العدد (42) ايلول - سبتهبر 2019

يتضح من الجدول (3) والثكل (2) أن قيمة "تات تساوي "49.112" وهي قيمة ذات دلالة إحصائية عند

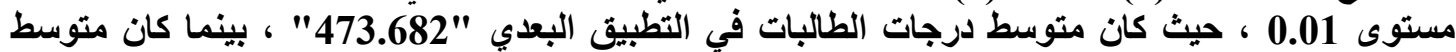
درجات الطالبات في التطبيق القبلي "66.744" ، مما يشير إلى وجودي فئ فروق حقيقية بين التطبيقين لصالح

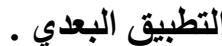
ولمعرفة حجم التأثير تم تطبيق معادلة ايتا : $=$ \begin{tabular}{l|c|c|}
$\mathbf{n}^{2}=$ & $\mathbf{t}^{2}$ & \multirow{2}{*}{$=0.99$}
\end{tabular}

$$
d=\frac{2 \sqrt{ } n^{2}}{\sqrt{1-n^{2}}}=19.8
$$

$$
\text { وبحساب حجم التأثير وجد إن } 0.99=\text { = n }
$$

ويتحدد حجم التأثير ما إذا كان كبيراً أو متوسطاً أو صغيراً كالأتي :

$$
\begin{aligned}
& 0.2 \\
& 0.5 \\
& 0.8 \text { = حجم تأثير كبير } 0.5
\end{aligned}
$$

\begin{tabular}{|c|c|c|c|c|c|c|}
\hline وستوى الدالاكة & قيمة ت & لدرجـات الحريـة & عدد أفراد & $\begin{array}{l}\text { المعياري } \\
\text { "عراف" }\end{array}$ & "الحستوسطي & \\
\hline \multirow{2}{*}{ 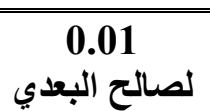 } & \multirow{2}{*}{30.115} & \multirow{2}{*}{19} & \multirow{2}{*}{20} & 1.290 & 8.456 & القبالـي \\
\hline & & & & 3.657 & 42.111 & البعـدي \\
\hline
\end{tabular}

وهذا يعنى أن حجم التأثير كبير ، وبذلك يتحقق الفرض الأول .

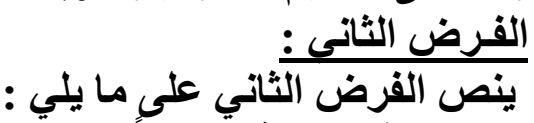

"توجد فروق دالة إحصائياً بين متّوسطي درجات الطالبات في التطبيق القبلي والبعدي للاختبار التحصيلي

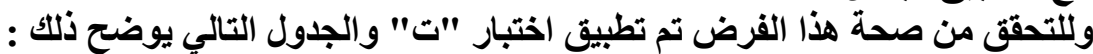

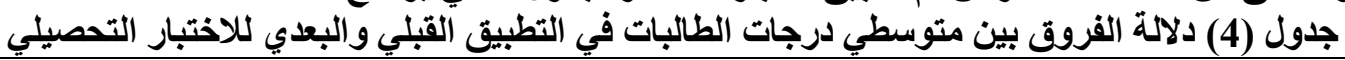

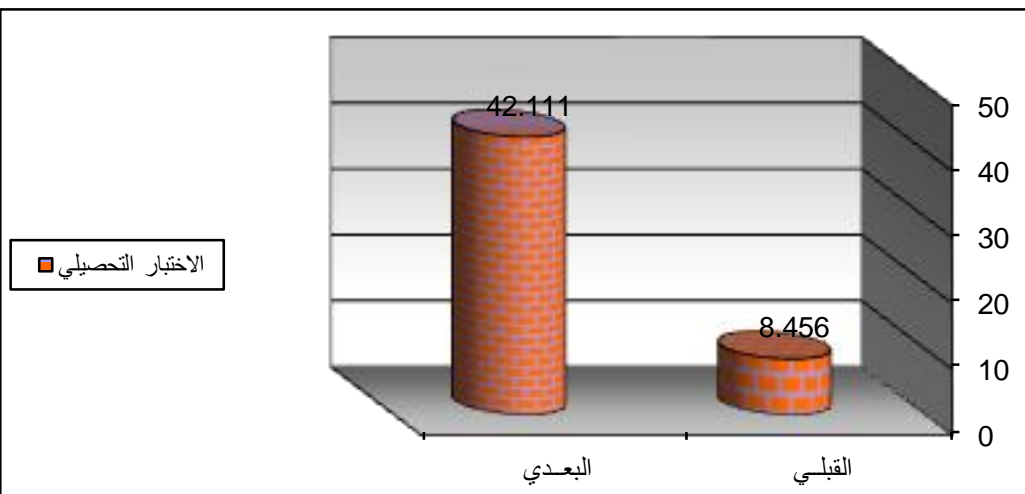

شكل (3) دلالة الفروق بين متوسطي درجات الطالبات في التطبيق القبلي والبعدي للاختبار التحصيلي 
مبلح (لفنون والأدب وعلوه الانسانيات و|لبانتماع|

Journal of Arts, Literature, Humanities and Social Sciences

ISSN online: 2414 - 3383

ISSN print: 2616 - 3810

العدد (42) ايلول - سبتهبر 2019

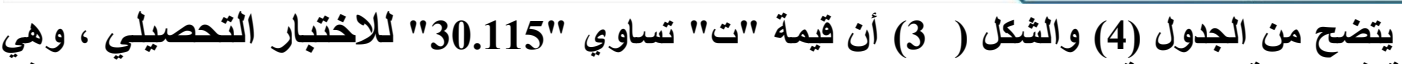

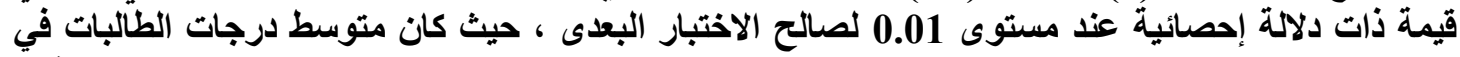

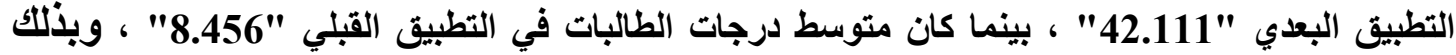

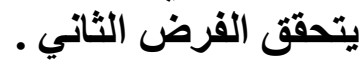

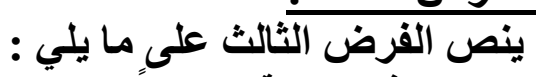

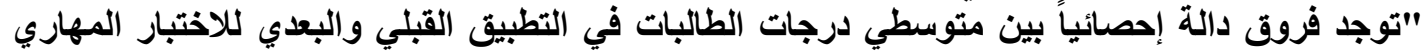

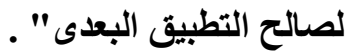
وللتحقق من صحة هذا الفرض تم تطبيق اختبار "ت" والجداول التالية توضح ذلك : جدول (5) دلالة القروق بين متوسطي درجات الطالبات في والئ

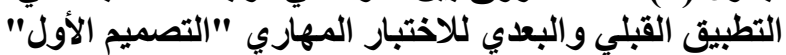

\begin{tabular}{|c|c|c|c|c|c|c|}
\hline مستوى الدالالة & قيمة ت & 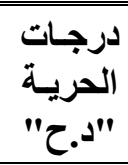 & "العينـة & المعياري & الحسابي & التصميم الأول \\
\hline \multirow{2}{*}{ لصالح البعدي } & \multirow{2}{*}{16.220} & \multirow{2}{*}{19} & \multirow{2}{*}{20} & 1.183 & 4.634 & القبلي \\
\hline & & & & 2.654 & 23.251 & البعداي \\
\hline
\end{tabular}

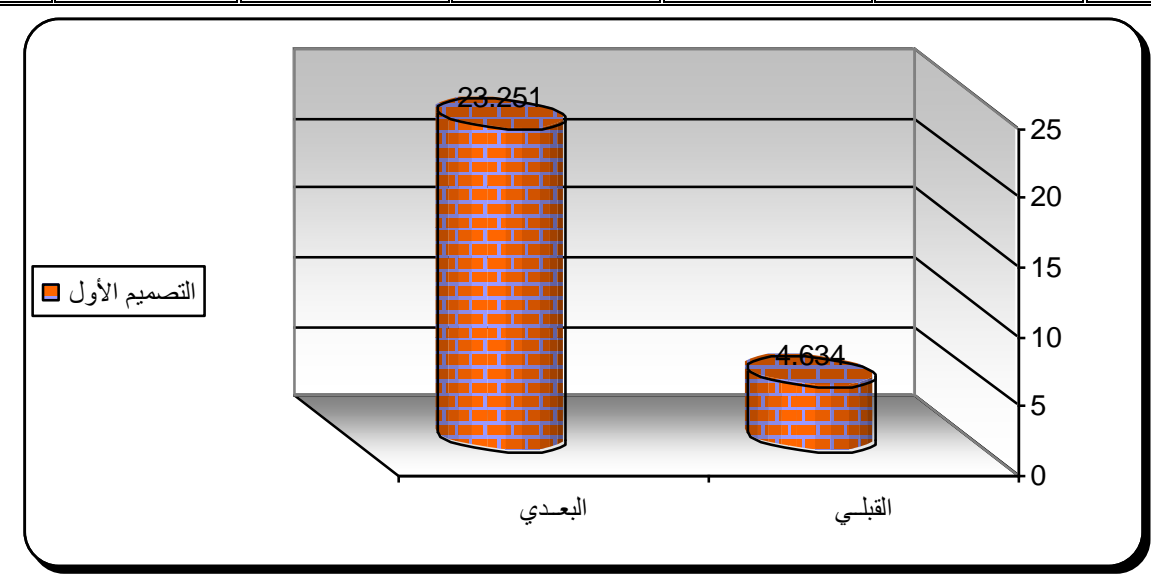

شكل (4) دلالة الفروق بين متوسطي درجات الطالبات في

التطبيق القبلي والبعدي للاختبار المهاري "التصنيم التصيم الأول"

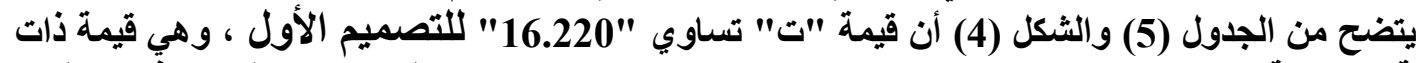

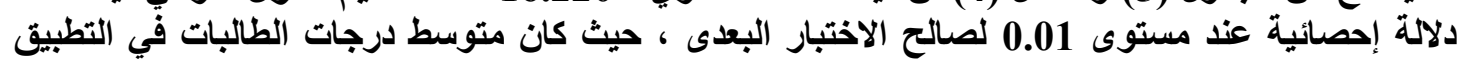

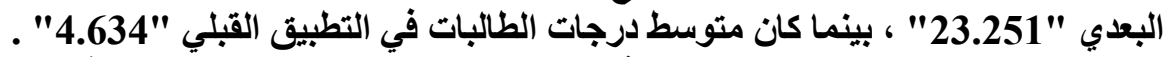

جدول (6) دلالة الفروق بين متوسطي درجات الطيات الطالبات في التئ

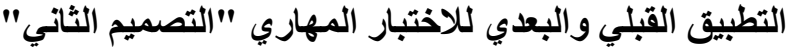

\begin{tabular}{|c|c|c|c|c|c|c|}
\hline مستوى الدالاية & قيمة ت & "درجــات & "العينـة أنزاد & الانحراف المعياري & "المسابي & التصميم الثاني \\
\hline \multirow{2}{*}{ 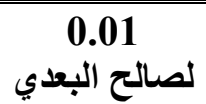 } & \multirow{2}{*}{22.196} & \multirow{2}{*}{19} & \multirow{2}{*}{20} & 1.776 & 5.819 & القبالـي \\
\hline & & & & 3.447 & 30.481 & البعـدي \\
\hline
\end{tabular}




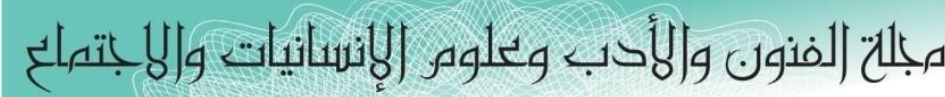
Journal of Arts, Literature, Humanities and Social Sciences

ISSN online: 2414 - 3383

ISSN print: 2616 - 3810 العدد (42) أيلول - سبتمبر 2019

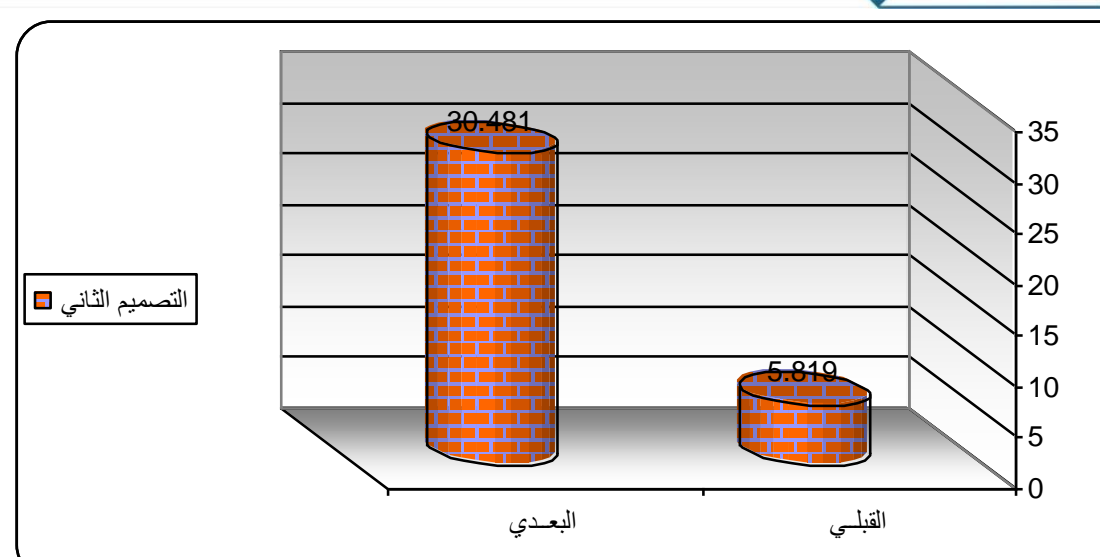

شكل (5) دلالة الفروق بين متوسطي درجات الطالبات في البواني

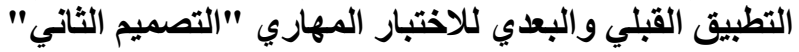

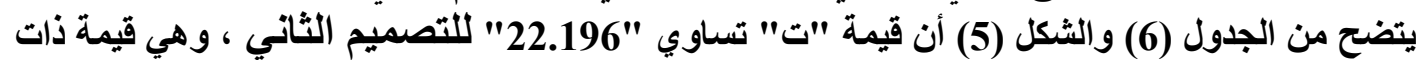

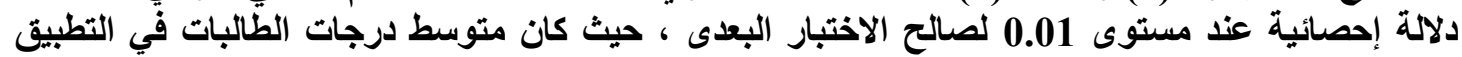

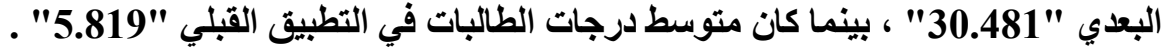

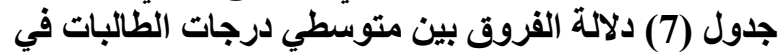

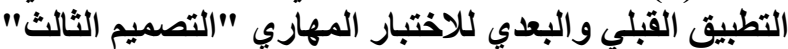

\begin{tabular}{|c|c|c|c|c|c|c|}
\hline وستوى الدالالة & قيمة ت & "لدرجـيـة & "العينة & المعياري & المستوبي & التصميم الثالث \\
\hline \multirow{2}{*}{ 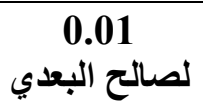 } & \multirow{2}{*}{18.725} & \multirow{2}{*}{19} & \multirow{2}{*}{20} & 1.394 & 6.178 & القبلـي \\
\hline & & & & 2.569 & 25.681 & البعـــي \\
\hline
\end{tabular}

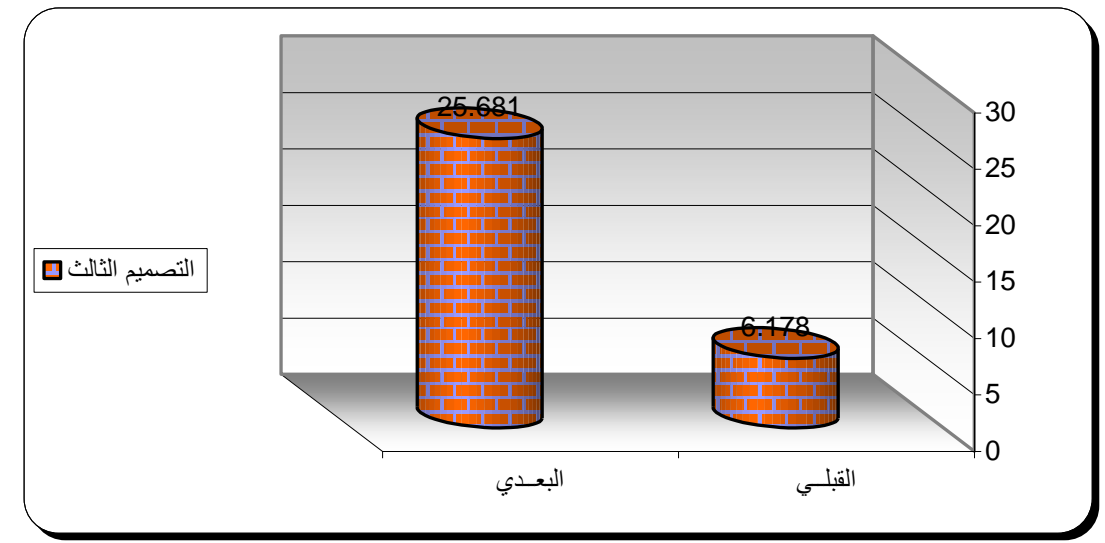

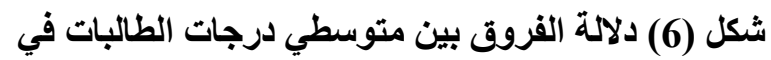

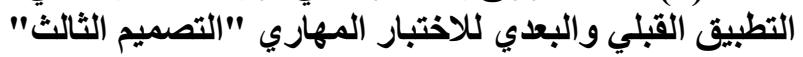

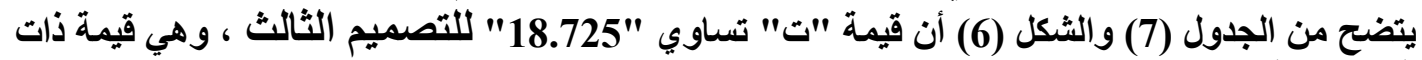

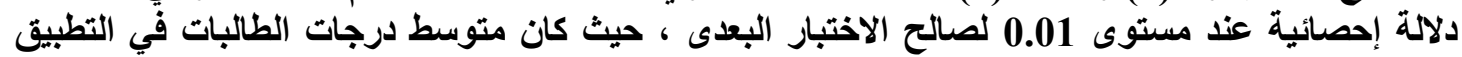

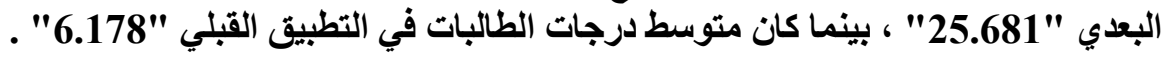




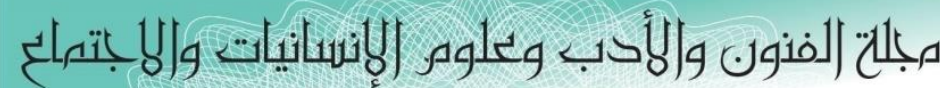

Journal of Arts, Literature, Humanities and Social Sciences

ISSN online: 2414 - 3383

ISSN print: 2616 - 3810

\section{العدد (42) أيلول - سبتمبر 2019}

جاول (8) دلالة الفروق بين متوسطي درجات الطالبات في

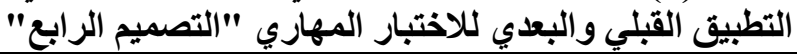

\begin{tabular}{|c|c|c|c|c|c|c|}
\hline مستوى الدالالة & قيمة ت & "لدرجــات & "العينـة & الالاعياري & المسابي & التصميم الرابع \\
\hline \multirow{2}{*}{ لصالح البعدي } & \multirow{2}{*}{26.391} & \multirow{2}{*}{19} & \multirow{2}{*}{20} & 1.654 & $\frac{1}{4.706}$ & القبلـي \\
\hline & & & & 2.513 & 32.625 & البعداي \\
\hline
\end{tabular}

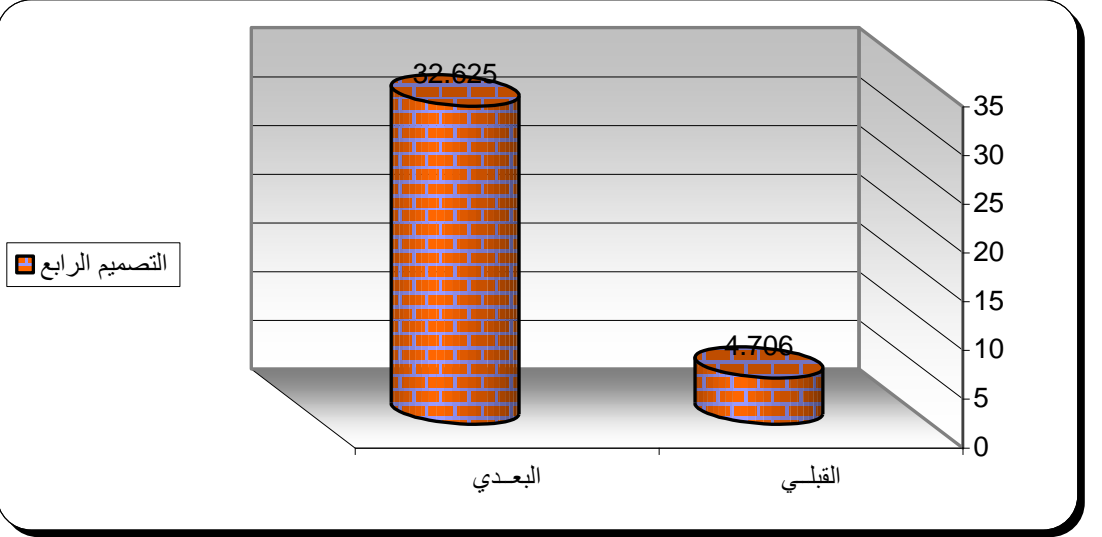

شكل (7) دلالة الفروق بين متوسطي درجات الطالبات في التطبيق القبلي والبعدي للاختبار المهاري "التصميم الرابع" التبات

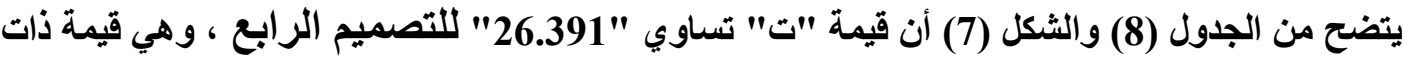

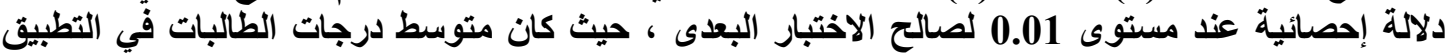

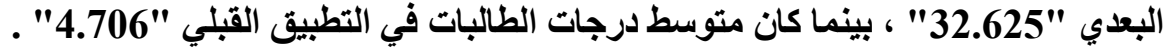
جدول (9) دلالة الفروق بين متوسطي درجات الطالبات في التطبيق القبلي والبعدي للاختبار المهاري "التصميم

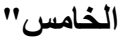

\begin{tabular}{|c|c|c|c|c|c|c|}
\hline مستوى الدالة & قيمة ت & "درجـات & عدد أفراد & "الأحياري & الحستوسي & التصميم الخامس \\
\hline \multirow{2}{*}{$\begin{array}{c}0.01 \\
\text { لصالح البعدي }\end{array}$} & \multirow{2}{*}{21.057} & \multirow{2}{*}{19} & \multirow{2}{*}{20} & 1.832 & 5.571 & القبلــي \\
\hline & & & & 2.661 & 29.024 & البعـدي \\
\hline
\end{tabular}

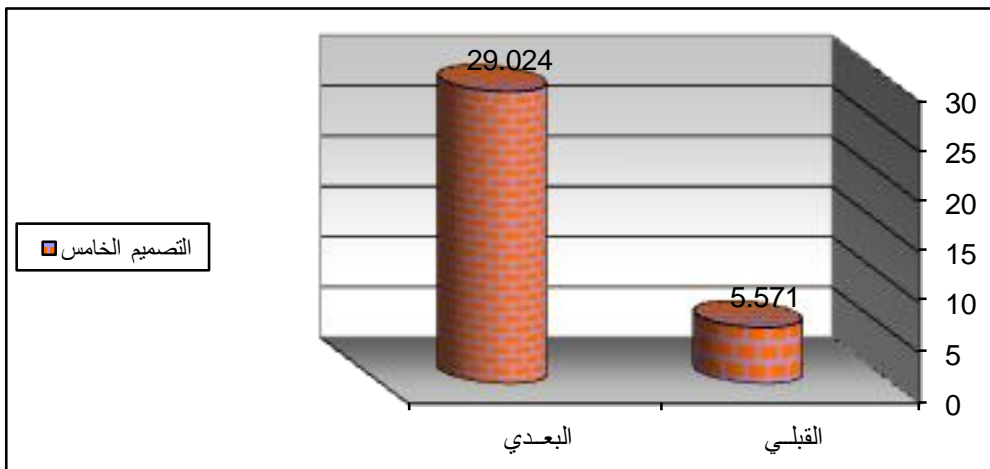

شكل (8) دلالة الفروق بين متوسطي درجات الطالبات في التطبيق القبلي والبعدي للاختبار المهاري "التصميم الخامس" في التطبر 


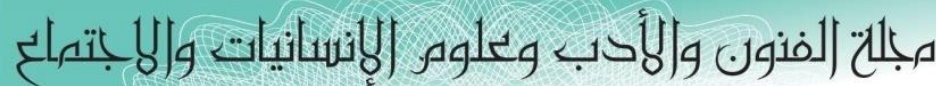

Journal of Arts, Literature, Humanities and Social Sciences

ISSN online: 2414 - 3383

ISSN print: 2616 - 3810

\section{العدد (42) أيلول - سبتهبر 2019}

LALHSS

Www.jalhss.com

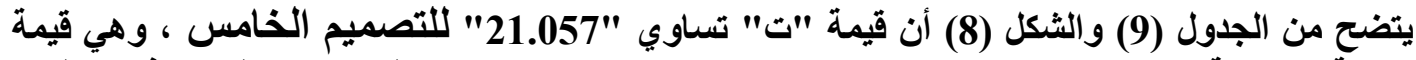

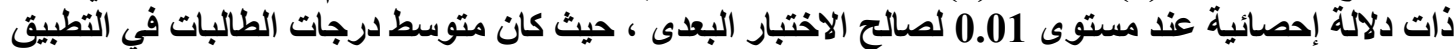

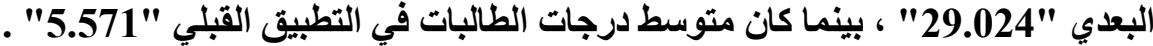

جدول (10) دلالة الفروق بين متوسطي درجات الطالبات في التطبيق القبلي والبعدي للاختبار المهاري "التصميم السادس" التبات

\begin{tabular}{|c|c|c|c|c|c|c|}
\hline مستوى الدالالة & قيمة ت & لدرجــــــات & "العينة & المعياري & الحستبي & السـصميم \\
\hline \multirow{2}{*}{ 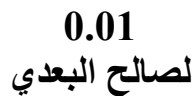 } & \multirow{2}{*}{15.243} & \multirow{2}{*}{19} & \multirow{2}{*}{20} & 1.930 & 2.247 & القبلــي \\
\hline & & & & 2.001 & 19.571 & البعـــي \\
\hline
\end{tabular}

شكل (9) دلالة الفروق بين متوسطي درجات الطالبات في التطبيق القبلي والبعدي للاختبار المهاري "التصميم السادس"

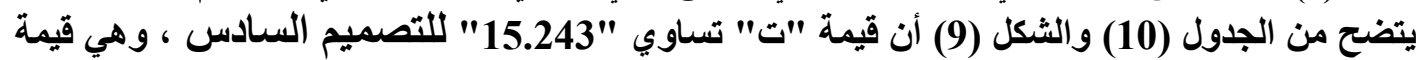

ذات دلالة إحصائية عند مستوى 0.01 لصالح الاختبار البعدى ، حيث كان متوسط درجات الطات الطالبات في التطبيق

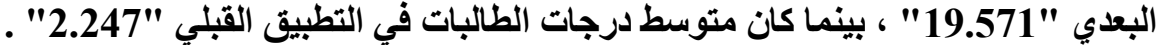

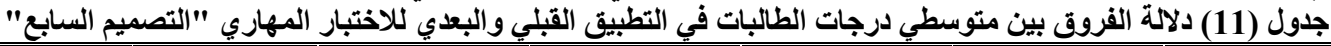

\begin{tabular}{|c|c|c|c|c|c|c|}
\hline مستوى الدالالة & قيمة ت & "لدرجـــــات & "العينة & "المعياري & الحستوسي & التصميم السابع \\
\hline \multirow{2}{*}{ 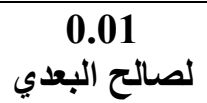 } & \multirow{2}{*}{19.091} & \multirow{2}{*}{19} & \multirow{2}{*}{20} & 1.021 & 3.067 & القبلـي \\
\hline & & & & 2.935 & 26.351 & البعـدي \\
\hline
\end{tabular}

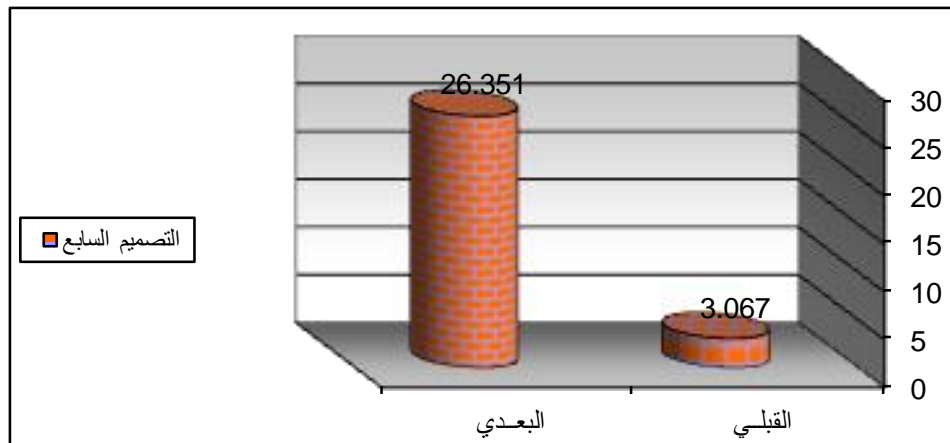

شكل (10) دلالة الفروق بين متوسطي درجات الطالبات في التطبيق القبلي والبعدي للاختبار المهاري "التصميم

السابع" 
مبلحة لفنون والأدب وعلوه الإنسانيات و|لبابتهاع

Journal of Arts, Literature, Humanities and Social Sciences

ISSN online: 2414 - 3383

ISSN print: 2616 - 3810

\section{العدد (42) أيلول - سبتمبر 2019}

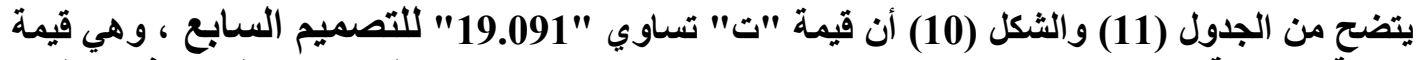

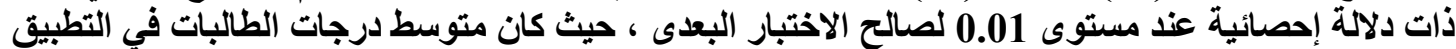

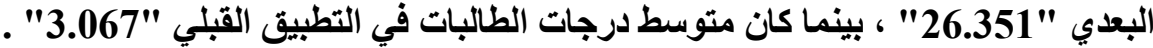

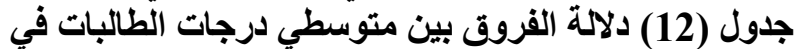

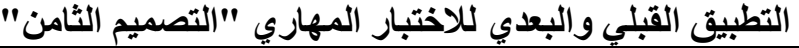

\begin{tabular}{|c|c|c|c|c|c|c|}
\hline مستوى الدلالة & قيمة ت & "الرجرحـة & "العينـة & المعياري & الحسابي & التصميم الثامن \\
\hline \multirow{2}{*}{$\begin{array}{c}0.01 \\
\text { لصالح البعدي }\end{array}$} & \multirow{2}{*}{32.203} & \multirow{2}{*}{19} & \multirow{2}{*}{20} & 1.823 & 4.992 & القبالـي \\
\hline & & & & 4.057 & 41.325 & البعـدي \\
\hline
\end{tabular}

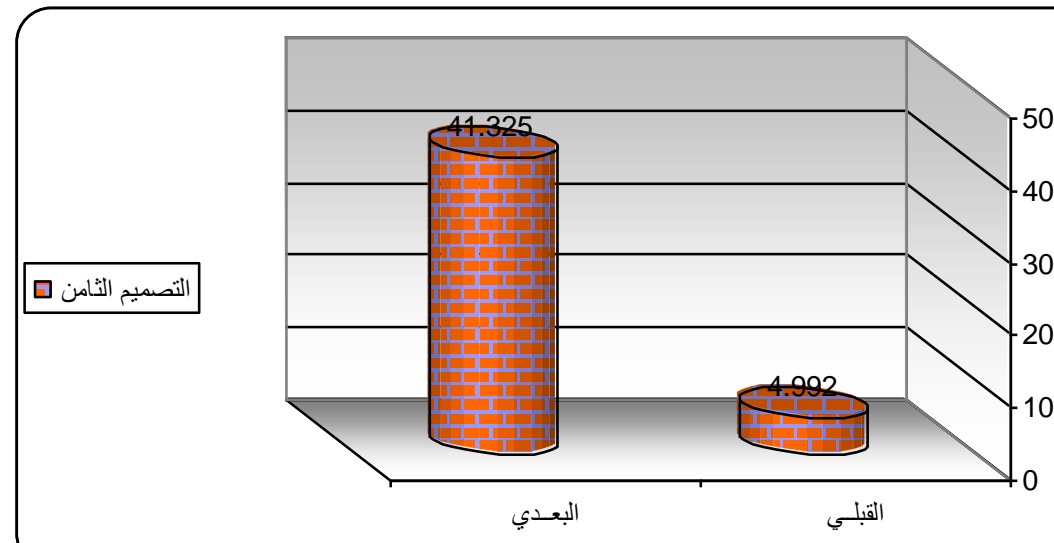

شكل (11) دلالة الفروق بين متوسطي درجات الطالبات في

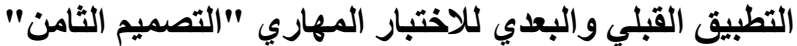

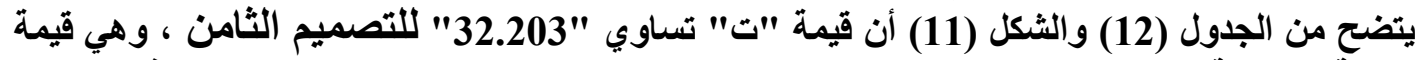

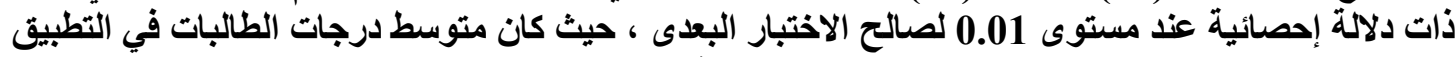

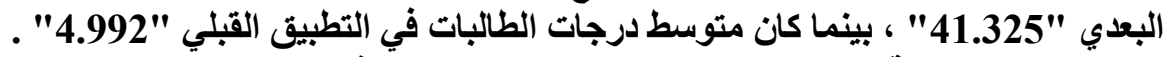

جدول (13) دلالة الفروق بين متوسطي درجات الطالبات في التطبيق القبلي والبعات البعي للاختبار المهاري "التصميم التاسع"

\begin{tabular}{|c|c|c|c|c|c|c|}
\hline مستوى الدالالة & قيمة ت & "لدرجـــة & "العينة & المعياري & الحسابي & التصميم التاسع \\
\hline \multirow{2}{*}{ 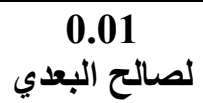 } & \multirow{2}{*}{30.410} & \multirow{2}{*}{19} & \multirow{2}{*}{20} & 1.448 & 3.017 & القبالـي \\
\hline & & & & 3.001 & 36.248 & البعـدي \\
\hline
\end{tabular}


مبلح" (لفنون والأدب وعلوه البانسانيات و|لهاتهماع Journal of Arts, Literature, Humanities and Social Sciences

ISSN online: 2414 - 3383

ISSN print: 2616 - 3810 العدد (42) أيلول - سبتهبر 2019

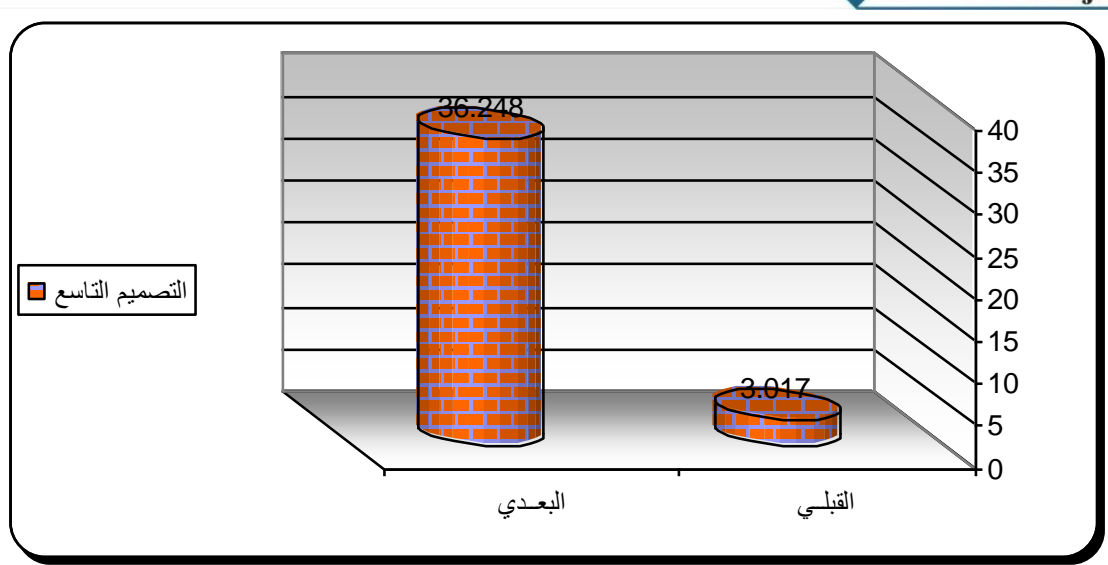

شكل (12) دلالة الفروق بين متوسطي درجات الطالبات في

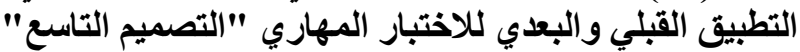

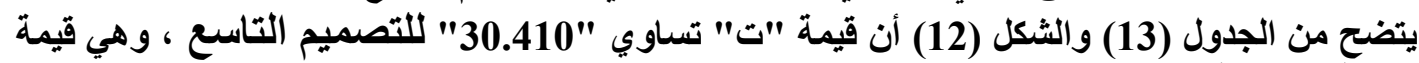

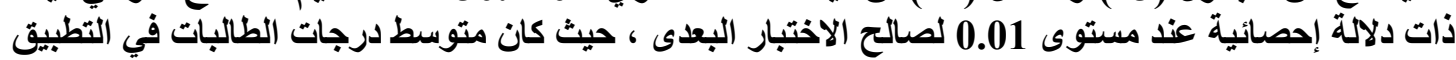
البعدي "36.248" ، بينما كان متوسط درجات الطالبات في التطبيق القبلي "3.01 "3.017" .

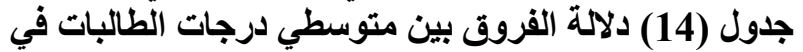

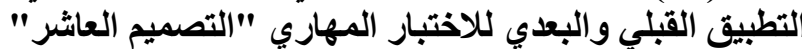

\begin{tabular}{|c|c|c|c|c|c|c|}
\hline مستوى اللالالة & قيمةت & "دالحريـة & العينـة & المعياري & الحسابي & التصميم العاشر \\
\hline \multirow{2}{*}{ لصالح البعدى 0.01} & \multirow{2}{*}{21.269} & \multirow{2}{*}{19} & \multirow{2}{*}{20} & 1.518 & 2.432 & القبــي \\
\hline & & & & 2.991 & 28.157 & البعدي \\
\hline
\end{tabular}

التصميم العائر

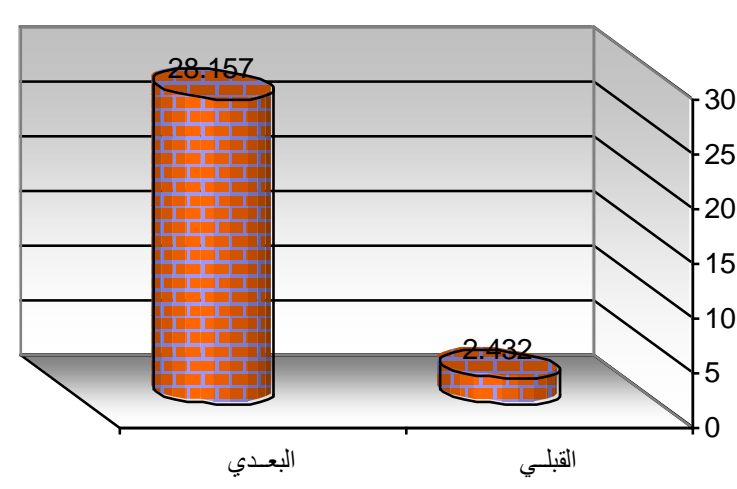

شكل (13) دلالة الفروق بين متوسطي درجات الطالبات في

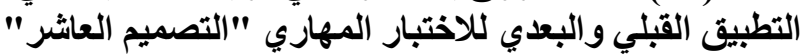

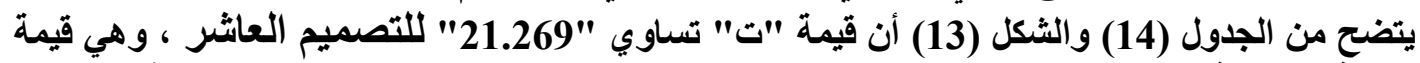

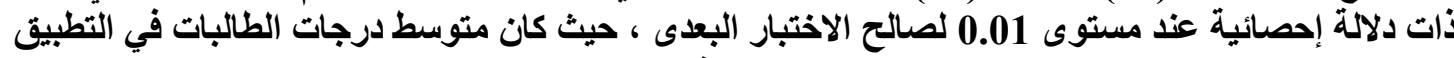
البعدي "28.157" ، بينما كان متوسط درجات الطالبات في التطبيق القبلي "2.432" . 


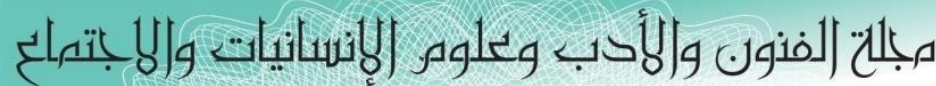
Journal of Arts, Literature, Humanities and Social Sciences

ISSN online: 2414 - 3383

ISSN print: 2616 - 3810

\section{العدد (42) أيلول - لسبتهبر 2019}

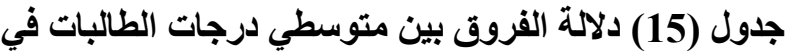

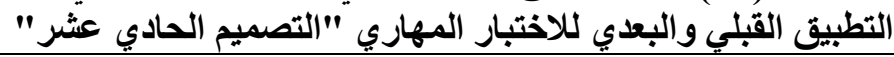

\begin{tabular}{|c|c|c|c|c|c|c|}
\hline مستوى الدالاة & قيمة ت & "درجـات & عدد أفز اد & 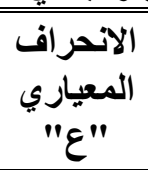 & 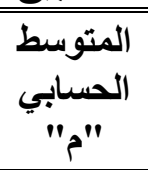 & الحادي عثيم \\
\hline \multirow{2}{*}{ 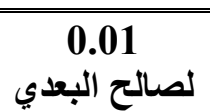 } & \multirow{2}{*}{15.529} & \multirow{2}{*}{19} & \multirow{2}{*}{20} & 1.201 & 2.294 & القبلـي \\
\hline & & & & 2.104 & 20.206 & البعـدي \\
\hline
\end{tabular}

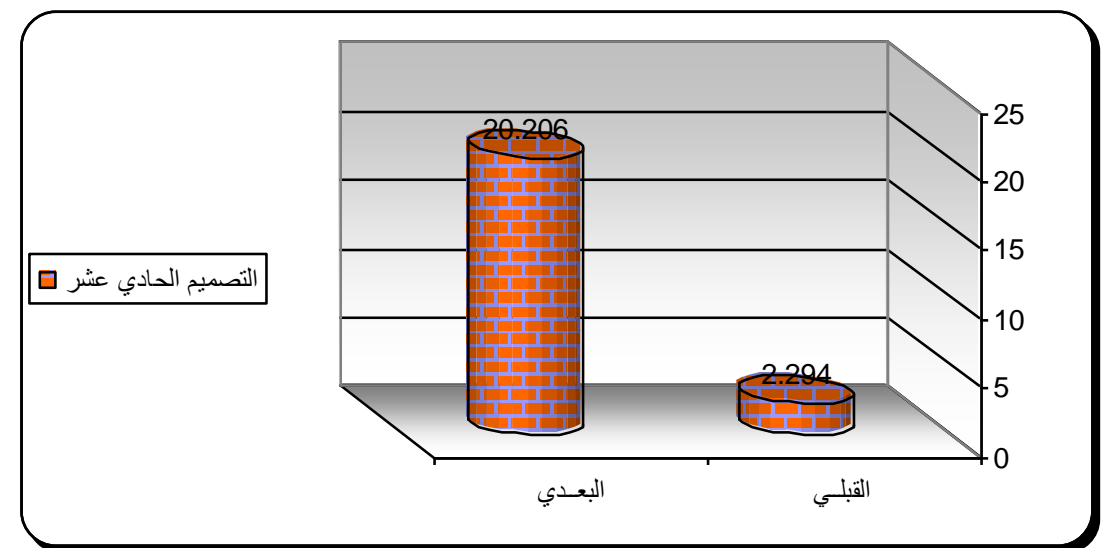

شكل (14) دلالة الفروق بين متوسطي درجات الطالبات في

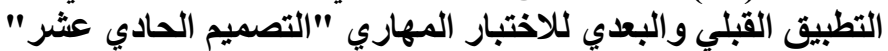

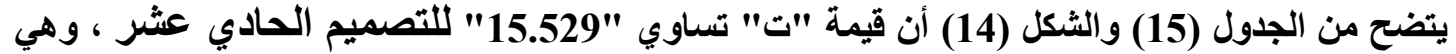

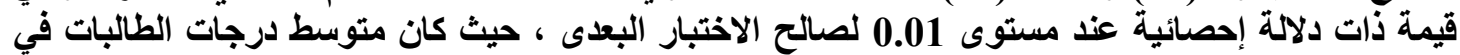
التطبيق البعدي "20.206" ، بينما كان متوسط درجات الطالبات في التطبيق القبلي "2.294" ـ جلول (16) دلالة الفروق بين متوسطي درجات الطالبات في

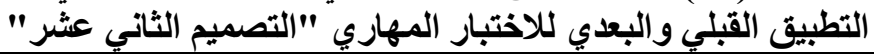

\begin{tabular}{|c|c|c|c|c|c|c|}
\hline مستوى الدلالة & قيمة ت & "درجـيـة & "العينة & الالعياري & المسابي & الثاني عشيم \\
\hline \multirow{2}{*}{$\begin{array}{c}0.01 \\
\text { لصالح البعدي }\end{array}$} & \multirow{2}{*}{27.439} & \multirow{2}{*}{19} & \multirow{2}{*}{20} & 1.806 & 3.487 & القبلـي \\
\hline & & & & 3.587 & 35.444 & البعـدي \\
\hline
\end{tabular}




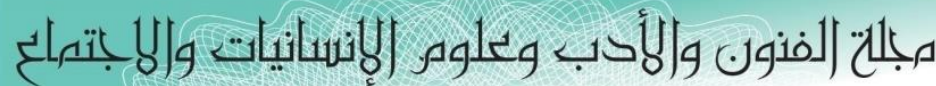
Journal of Arts, Literature, Humanities and Social Sciences

ISSN online: 2414 - 3383

ISSN print: 2616 - 3810

العدد (42) أيلول - سبتهبر 2019

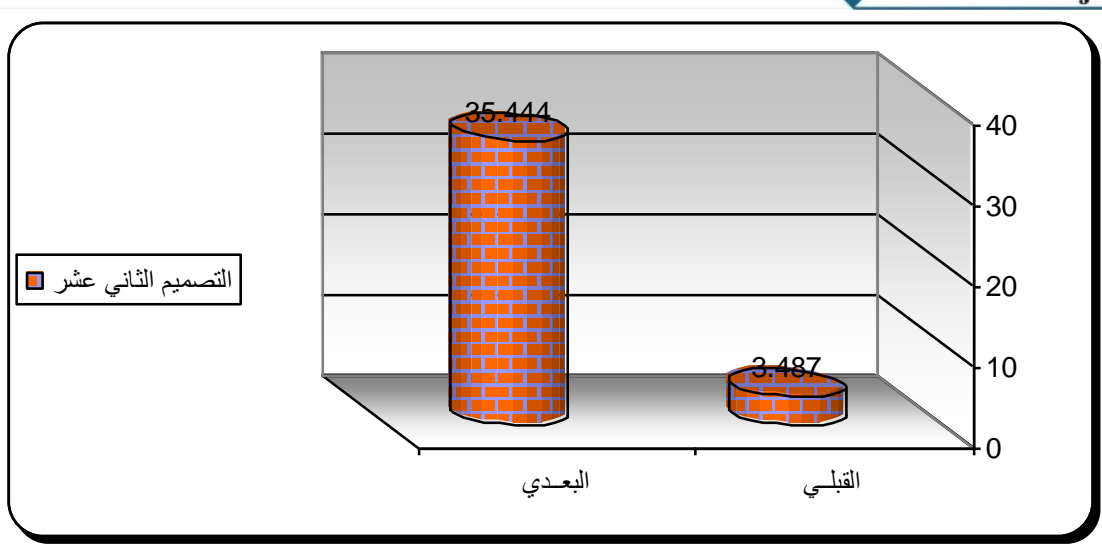

شكل (15) دلالة الفروق بين متوسطي درجات الطالبات في التطبيق القبلي والبعدي للاختبار المهاري

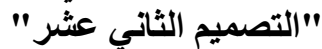

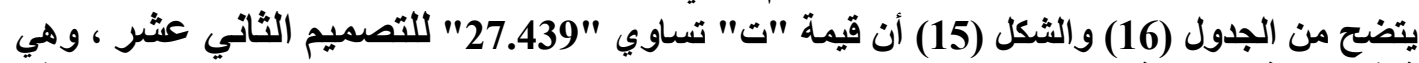

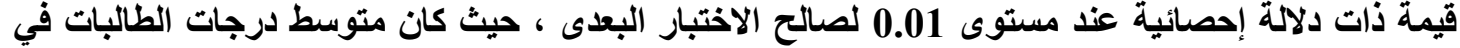

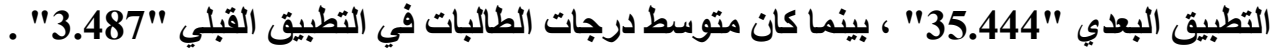

جدول (17) دلالة الفروق بين متوسطي درجات الطالبات في

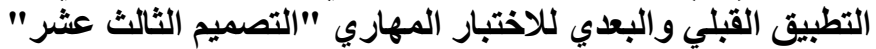

\begin{tabular}{|c|c|c|c|c|c|c|}
\hline مستوى الدلالة & قيمة ت & "درجــــــات & عدد أقرّاد & $\begin{array}{l}\text { المعياري } \\
\text { "عراف" } \\
\end{array}$ & 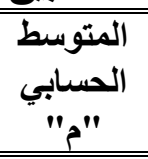 & الثالث عشيم التصري \\
\hline \multirow{2}{*}{$\begin{array}{c}0.01 \\
\text { لصالح البعدي }\end{array}$} & \multirow{2}{*}{18.532} & \multirow{2}{*}{19} & \multirow{2}{*}{20} & 1.335 & 2.406 & القبالـي \\
\hline & & & & 2.008 & 23.247 & البعـدي \\
\hline
\end{tabular}

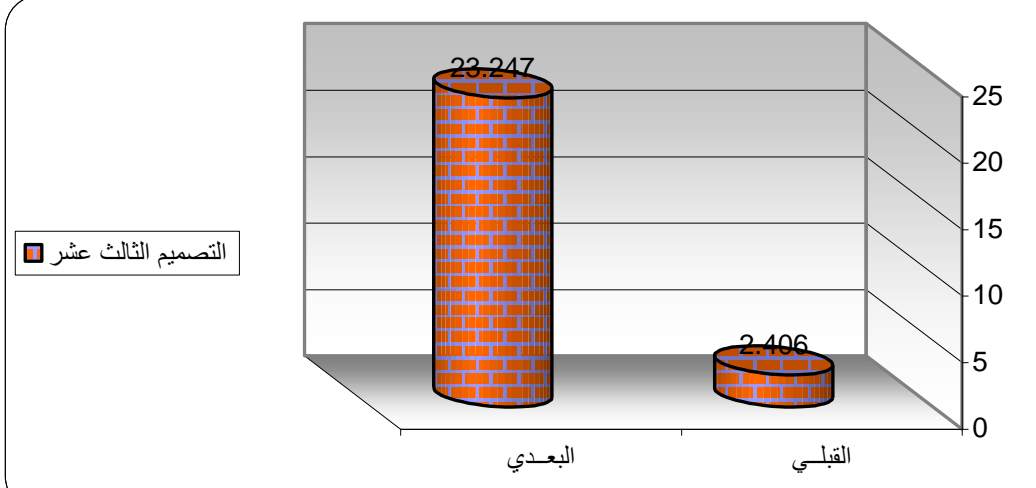

شكل (16) دلالة الفروق بين متوسطي درجات الطالبات في

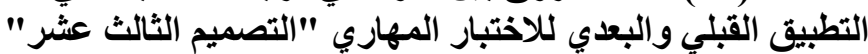

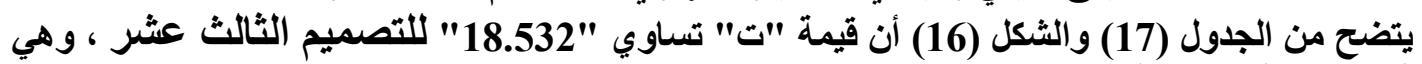

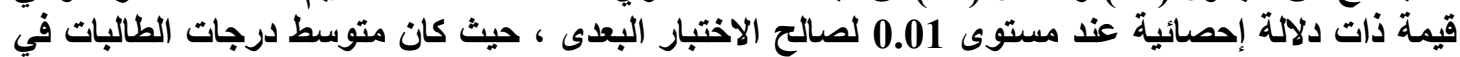
التطبيق البعدي "23.247" ، بينما كان متوسط درجات الطالبات في التطبيق القبلي "2.406" . 


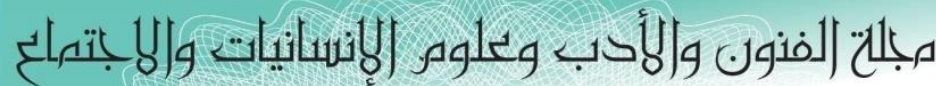

Journal of Arts, Literature, Humanities and Social Sciences

ISSN online: 2414 - 3383

ISSN print: 2616 - 3810

\section{العدد (42) أيلول - لسبتهبر 2019}

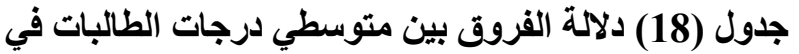

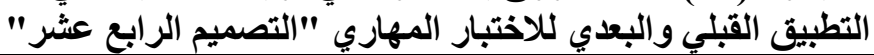

\begin{tabular}{|c|c|c|c|c|c|c|}
\hline مستوى الدلالة & قيمة ت & "درجـــــاتة & "عديد أفراد & الععياري & الحسابي & الرابع عشيم التصر \\
\hline \multirow{2}{*}{ لصالح البعدي } & \multirow{2}{*}{21.001} & \multirow{2}{*}{19} & \multirow{2}{*}{20} & 1.224 & 3.957 & القبلـي \\
\hline & & & & 2.429 & 28.810 & البعـدي \\
\hline
\end{tabular}

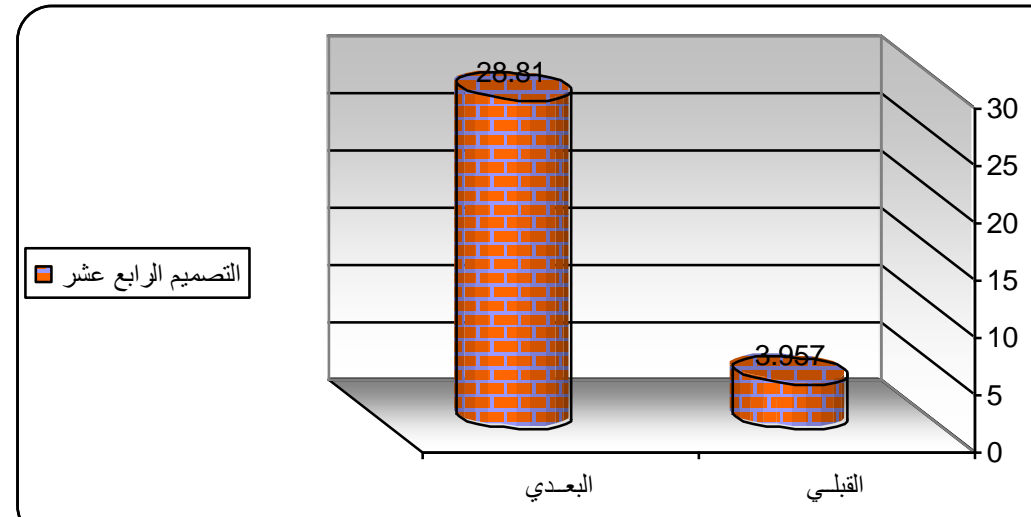

شكل (17) دلالة الفروق بين متوسطي درجات الطالبات في

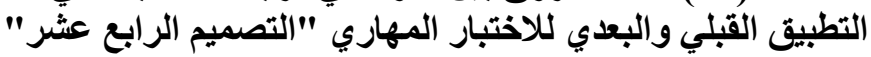

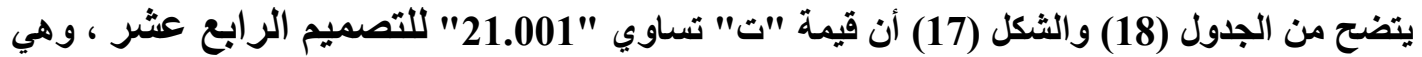

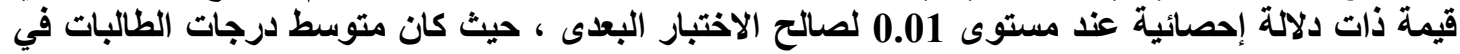

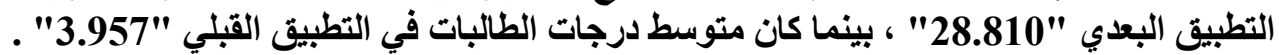

جدول (19) دلالة الفروق بين متوسطي درجات الطالبات في

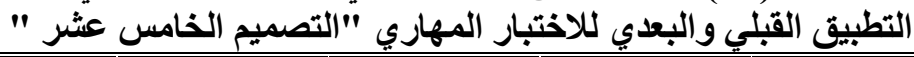

\begin{tabular}{|c|c|c|c|c|c|c|}
\hline مستوى الدلالة & قيمة ت & "درجــاتة & "العينة & العياري الانحراف & "الحستبي & الخامس عشمر \\
\hline \multirow{2}{*}{$\begin{array}{c}0.01 \\
\text { لصالح البعدي }\end{array}$} & \multirow{2}{*}{22.219} & \multirow{2}{*}{19} & \multirow{2}{*}{20} & 1.005 & 3.481 & القبالبي \\
\hline & & & & 3.058 & 31.150 & البعـدي \\
\hline
\end{tabular}


مبلح (لفنون والأدب وعلوه الانسانيات و|لبانتماع|

Journal of Arts, Literature, Humanities and Social Sciences

ISSN online: 2414 - 3383

ISSN print: 2616 - 3810

العدد (42) أيلول - سبتهبر 2019

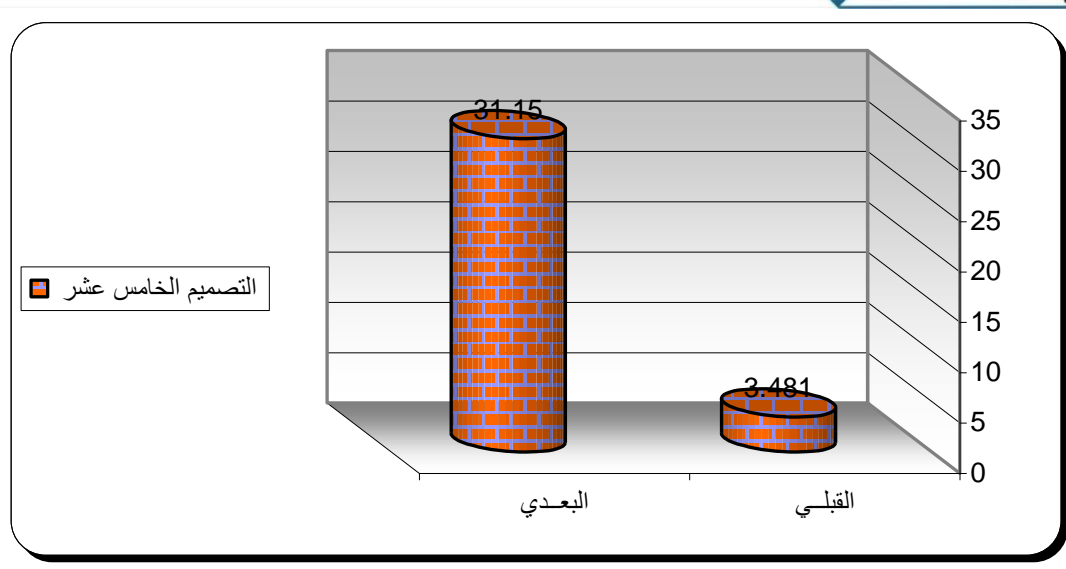

شكل (18) دلالة الفروق بين متوسطي درجات الطالبات في عيد

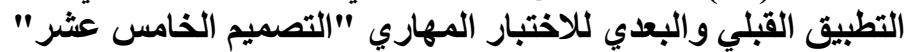

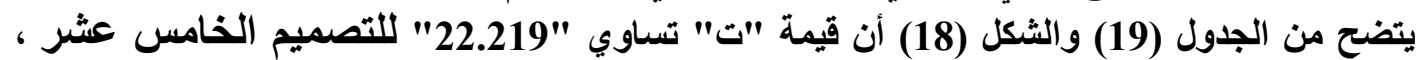

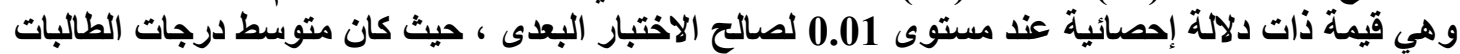
في التطبيق البدي "31.150" ، بينما كان متوسط درجات الطالبات في التطبيق القبلي "3.481" .

\begin{tabular}{|c|c|c|c|c|c|c|}
\hline \multicolumn{7}{|c|}{ 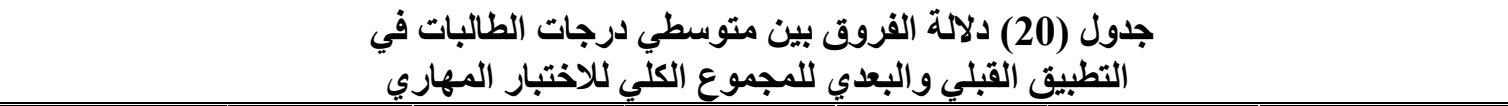 } \\
\hline مستوى الدالالة & قيمةت & "درجرجـة & علعد أنقرة & "العياري & الحسابي & المهاري ككل \\
\hline \multirow{2}{*}{ ل } & \multirow{2}{*}{45.325} & \multirow{2}{*}{19} & \multirow{2}{*}{20} & 5.006 & $\begin{array}{l}58.288 \\
\end{array}$ & القبالبي \\
\hline & & & & 11.670 & 431.571 & البعـدي \\
\hline
\end{tabular}

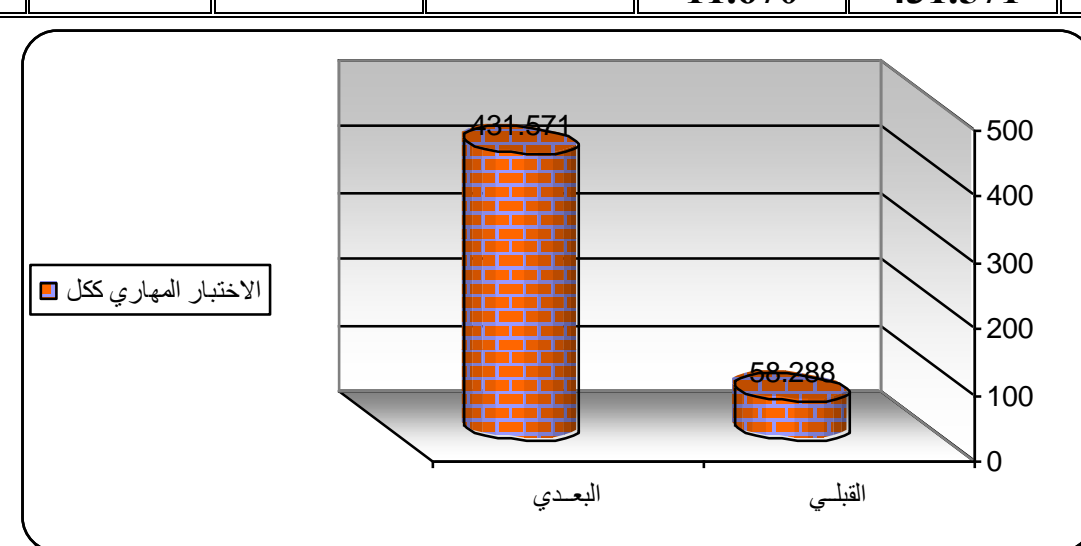

شكل (19) دلالة الفروق بين متوسطي درجات الطالبات في

التطبيق القبلي والبعدي للمجموع الكلي للاختبار المهاري

يتضح من الجدول (20) والشكل (19) أن قيمة "ت" تساوي "45.325" للمجموع الكلي للاختبار

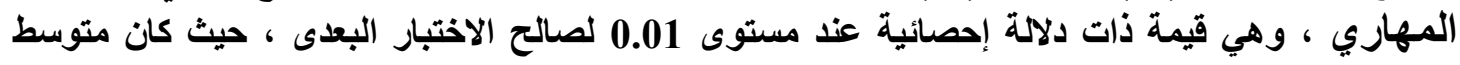




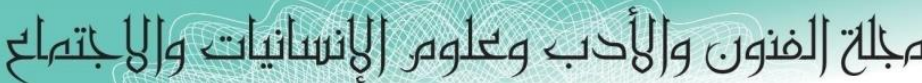

Journal of Arts, Literature, Humanities and Social Sciences

ISSN online: 2414 - 3383

ISSN print: 2616 - 3810

\section{العدد (42) أيلول - سبتمبر 2019}

درجات الطالبات في التطبيق البعدي "431.571" ، بينما كان متوسط درجات الطالبات في التطبيق القبلي

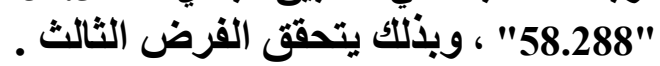

1- التوصيـات : الانفتاح على العالم والإطلاع على الأساليب الحديثة في التعليم من خلال دمج الاستراتيجيات التعليمية

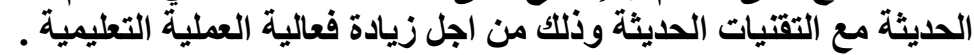

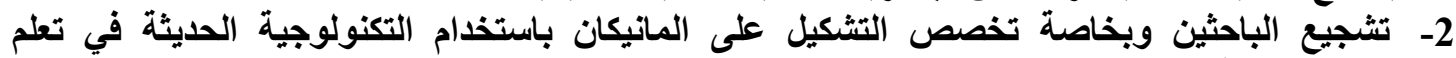

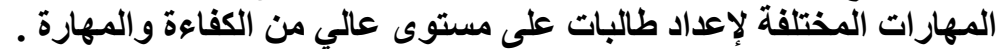

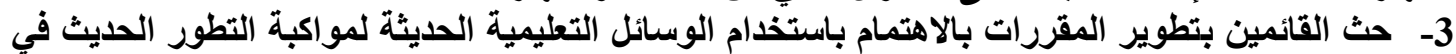

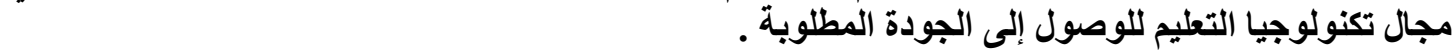

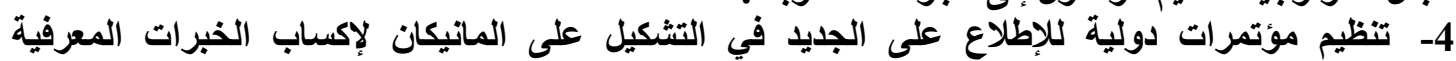
والمهارية. 5- استخذام أنواع أخري من الاستراتيجيات التعليمية الحديثة ومقارنتها بالطريقة المستخدمة .

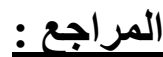
1- إبراهيم المنيف (2008م) : الإدارة - المفاهيم- الأسس- المهام ، الطبعة الرابعة ، دار العلم للطباعة والنثر 2- إير اهنم حسن (2008م) : تكنولوجيا التعليم و التدريب ، القاهرة

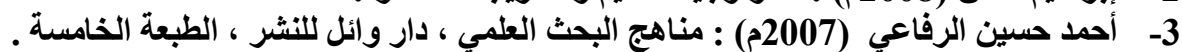

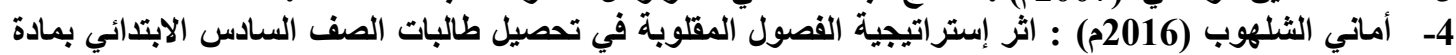

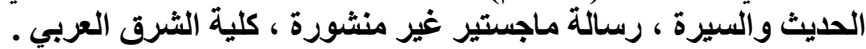
5- أنا كروس (2014م) : مدخل الصف المقلير منوب ، شكسبير في حصص اللغة الإنجليزية ، رسالة ماجستير ، جامعة

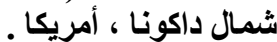
6- إيريك شوانكي (2013م) : التعليم المدمج ، التحصيل والتصور ، الأثر علي التحصيل وتصورات الطلاب ، رسالة

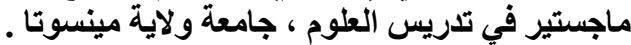

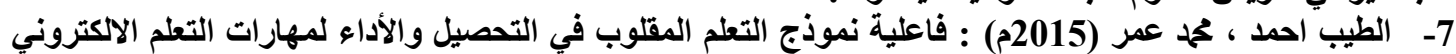

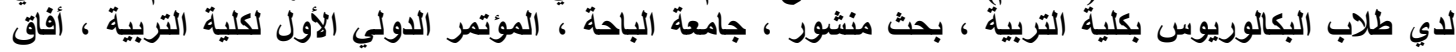

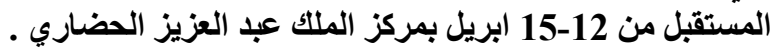

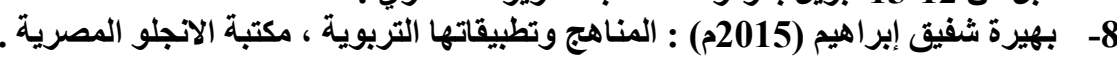

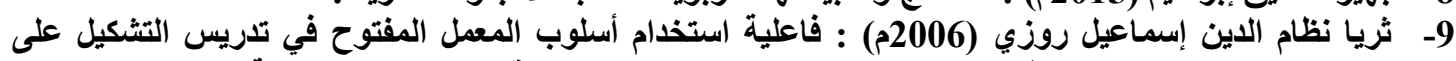

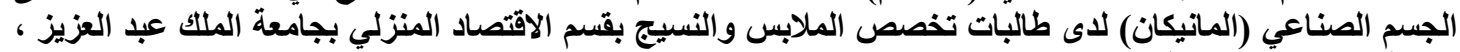
رسالة ماجستير ، جامعة الملك عبد العزيز البرات ، جدة.

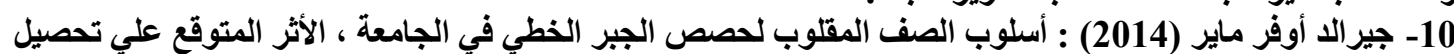
الطلاب ، رسالة دكتور اه جاه ، جامعة ولاية كولور ادو ، أمريكا.

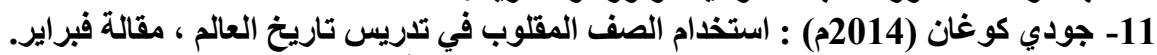

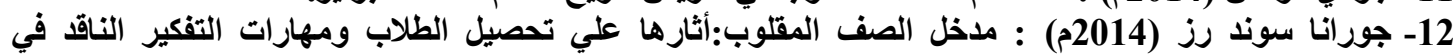

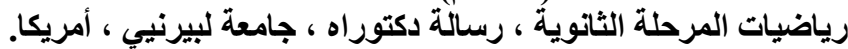

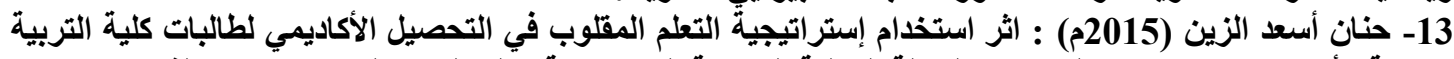

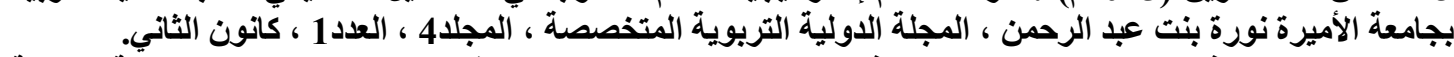

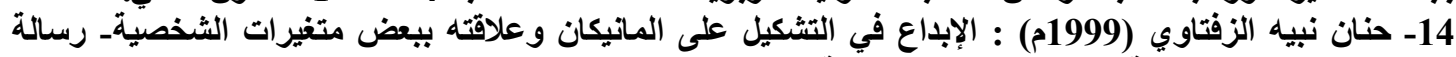

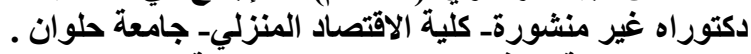

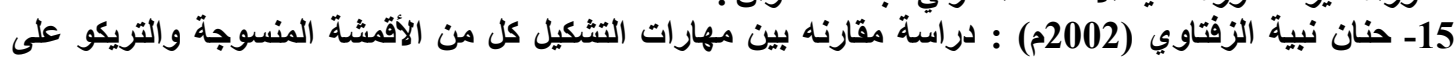
المانيكان ، مؤتمر الاقتصاد المنزلي.

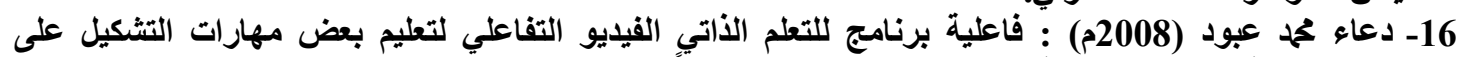

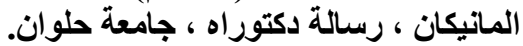
17- ذوقان عبيدات ، أبو سميد سهيلة (2004م) : استراتيجيات التدريس . 


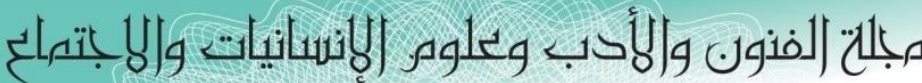

Journal of Arts, Literature, Humanities and Social Sciences

ISSN online: 2414 - 3383

ISSN print: 2616 - 3810

\section{العدد (42) أيلول - سبتمبر 2019}

18- سانغ كيم ، نام بارك (2014م) : أثر أسلوب الصف المعكوس المستتد علي التعلم الأكي علي التعلم الذاتي والتعلم - التم

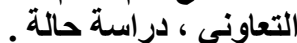

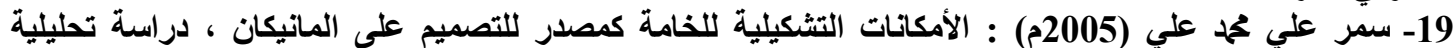

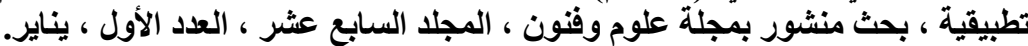

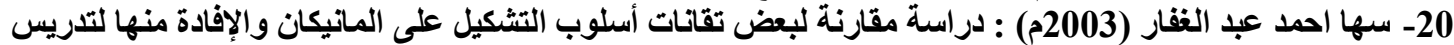

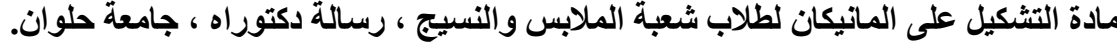

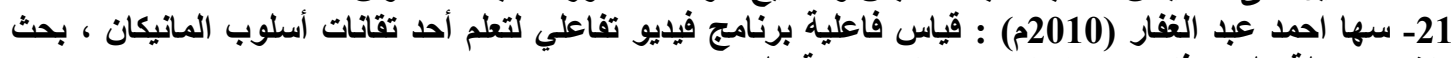

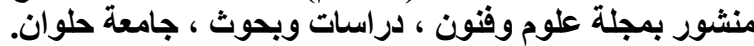

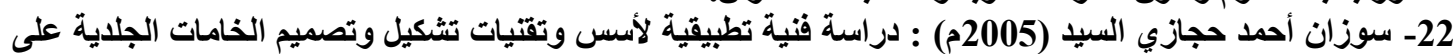

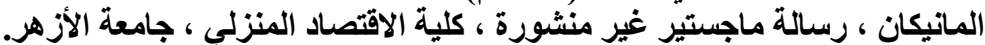

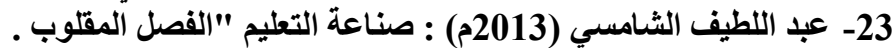

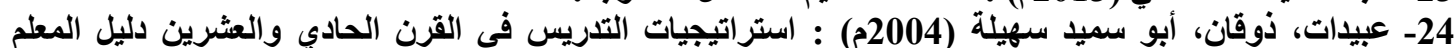
والمشرف التربوي ، الرياض دوان، أبو ، مركز ديبونو لتعليم التفكير.

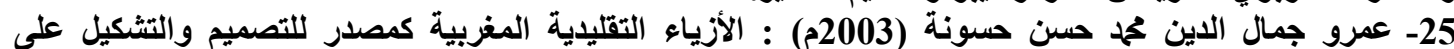

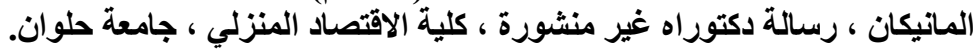

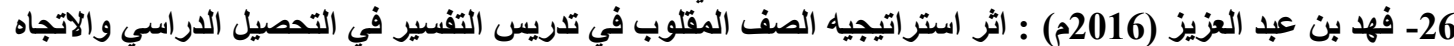

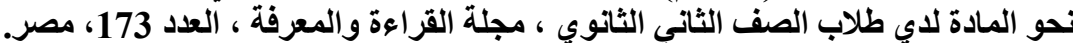

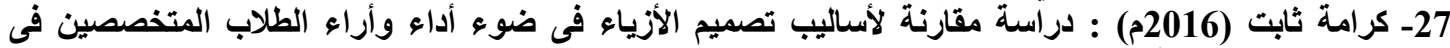

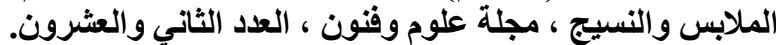

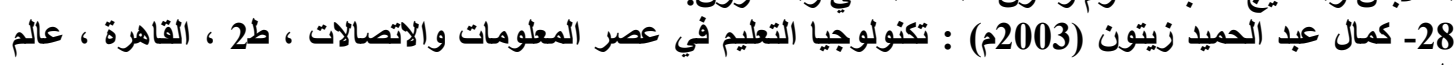
الكتب .

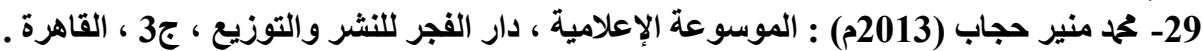

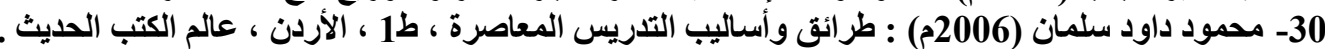

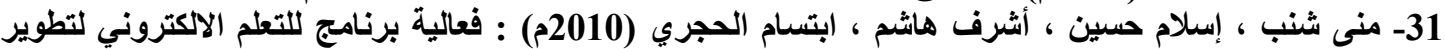

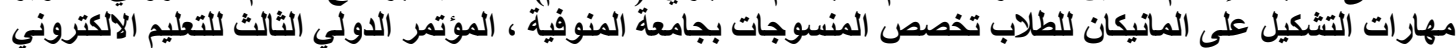

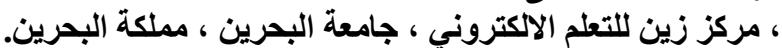

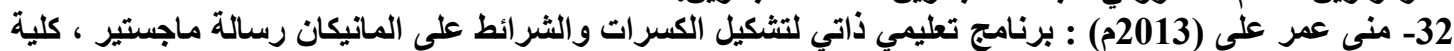

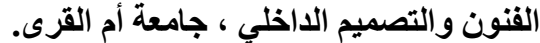

33- نبيل السبد فحمد (2015م) : فاعلية التعلم المعكوس القائم علي تدوين المرئي في تنمية مهارات تصميم الاختبارات الاكترونية لاي أعضاء هيئة التدريس بجامعة أم القرى ، دراسات عربية في التربية وعلم التئة فئة التفس ، العدد (61) السعودية . 34- نجلاء جابر الثبيتي (2009م) : دراسة قابلية تشكيل الأقشة على الماتيكان لتصميم ملابس المرأة ، رسالة دكتوراه

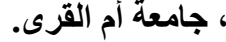

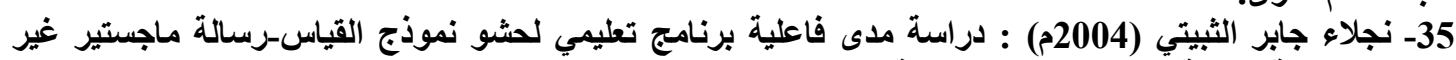

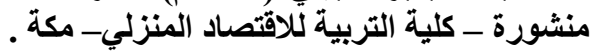

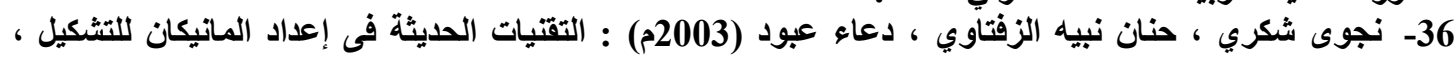
القاهرة ، عالم الكتب

37- نجوى شكري (2006م) : نجئ : التشكيل على المانيكان ، دار الفكر العربي، القاهرة.

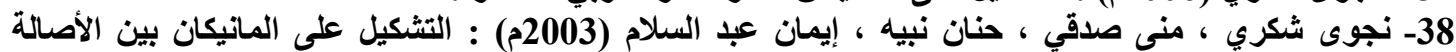

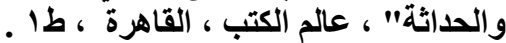
39- نجوى شكري (2001م) : التشكيل علي المانيكان، تطوره ، عناصره ، أسسه ، أساليبه ، ثُقافاته المعاصرة ، دار

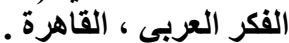
40- نصر الله عحمد محمود (2016) : المدخل إلي استراتيجيات التدريس ، ط1 ، القاهرة ، عالم الكتب .

41- http://eduongo.net/2015/10/29/bill-gates-talks about-flipped-learning. 